\title{
An Efficient Method for the Construction of Functionalized DNA Bearing Amino Acid Groups through Cross-Coupling Reactions of Nucleoside Triphosphates Followed by Primer Extension or PCR
}

\author{
Petr Čapek, ${ }^{[a]}$ Hana Cahová, ${ }^{[a]}$ Radek Pohl, ${ }^{[a]}$ Michal Hocek, *[a] \\ Christian Gloeckner, ${ }^{[b]}$ and Andreas Marx ${ }^{*[b]}$
}

\begin{abstract}
Single step aqueous cross coupling reactions of nucleobase halo genated $2^{\prime}$ deoxynucleosides ( 8 bromo $2^{\prime}$ deoxyadenosine, 7 iodo 7 deaza $2^{\prime}$ deoxyadenosine, or 5 iodo $2^{\prime}$ deoxy ur idine) or their $5^{\prime}$ triphosphates with 4 boronophenylalanine or 4 ethynylphe nylalanine have been developed and used for efficient synthesis of modified 2' deoxynucleoside triphosphates (dNTPs) bearing amino acid groups. These dNTPs were then tested as sub strates for DNA polymerases for con struction of functionalized DNA through primer extension and PCR.
\end{abstract}

While 8 substituted adenosine triphos phates were poor substrates for DNA polymerases, the corresponding $7 \mathrm{sub}$ stituted 7 deazaadenine and 5 substi tuted uracil nucleotides were efficiently incorporated in place of dATP or dTTP, respectively, by Pwo (Pyrococ cus woesei) DNA polymerase. Nucleo tides bearing the amino acid connected through the less bulky acetylene linker

Keywords: cross coupling • DNA • nucleosides • nucleotides • poly merase chain reaction were incorporated more efficiently than those directly linked through a more bulky phenylene group. In addi tion, combinations of modified dATPs and dTTPs were incorporated by $P$ wo polymerase. Novel functionalized DNA duplexes bearing amino acid moieties were prepared by this two step ap proach. PCR can be used for amplifica tion of duplexes bearing large number of modifications, while primer exten sion is suitable for introduction of just one or several modifications in a single DNA strand.

\section{Introduction}

Functional nucleic acids (e.g., DNA aptamers, DNAzymes, etc.) are attracting growing interest due to their potential applications in chemical biology, bioanalysis, or nanotech nology. ${ }^{[1]}$ To expand the scope of these applications, the in troduction of a variety of functional groups into DNA (espe cially into the nucleobase components) is desirable. Apart from classical oligonucleotide synthesis ${ }^{[2]}$ using functional ized nucleoside phosphoramidites or post synthetic oligonu

[a] Dr. P. Čapek, H. Cahová, Dr. R. Pohl, Prof. Dr. M. Hocek

Gilead Sciences \& IOCB Research Center

Institute of Organic Chemistry and Biochemistry, v. v. i.

Academy of Sciences of the Czech Republic

Flemingovo nam. 2, 16610 Prague 6 (Czech Republic)

Fax: (+420)220183559

Email: hocek@uochb.cas.cz

[b] C. Gloeckner, Prof. Dr. A. Marx

Department of Chemistry, University of Konstanz

78457 Konstanz (Germany)

Fax: (+49) 7531885140

E mail: Andreas.Marx@uni konstanz.de cleotide modifications, ${ }^{[3]}$ nucleobase functionalized DNA can also be prepared by incorporation of modified nucleo side triphosphates (dNTPs) with the aid of DNA poly merases. ${ }^{[410]}$ This approach using PCR incorporation of functionalized dNTPs is particularly interesting because of its potential for use in in vitro selection. Recently, several types of modified DNA bearing diverse groups, for example, aminoalkynyl or aminoalkyl ${ }^{[46]}$ and several types of attached functional molecules, for example, biotin, ${ }^{[6]}$ acridones, ${ }^{[7]}$ fer rocene, ${ }^{[8]}$ amino acids, ${ }^{[9]}$ carbohydrates, ${ }^{[10]}$ or fluorescein labels, ${ }^{[11]}$ have been prepared from the corresponding modi fied dNTPs by this methodology. The dNTP building blocks are usually prepared ${ }^{[49]}$ by troublesome and laborious tri phosphorylation of the corresponding modified nucleosides, in which the functional groups usually have to be protected and deprotected.

We have very recently developed an efficient and rapid single step synthesis ${ }^{[12]}$ of modified nucleosides, nucleotides, and nucleoside triphosphates bearing phenylalanine moiet ies through aqueous phase cross coupling reactions ${ }^{[13]}$ be tween the corresponding unprotected 8 bromoadenine bio molecules and 4 boronophenylalanine. Although an exam 
ple of a Sonogashira reaction of 5 iodo dUTP had been known previously, ${ }^{[11]}$ this was the first example of direct cross coupling modification of a purine dNTP. Soon after, other groups reported similar Suzuki Miyaura reactions be tween 8 bromoGTP and boronic acids ${ }^{[14]}$ and coupling of a chloromercury derivative of dUTP with carbohydrate conju gated acrylamide derivatives. ${ }^{[10]}$ Here we report on the ex tension of the aqueous phase Suzuki Miyaura cross cou pling methodology to 7 iodo 7 deazaadenine and 5 iodoura cil nucleosides and dNTPs, on the development of related aqueous phase Sonogashira reactions with an amino acid linked acetylene, and on the incorporation of these modified dNTPs by DNA polymerases.

\section{Results and Discussion}

Synthesis of modified nucleosides and dNTPs: Cross cou pling reactions are efficient tools for the introduction of carbon substituents into nucleobases and nucleosides. ${ }^{[15]}$ Until recently, the reactions were usually performed in or ganic solvents on protected nucleosides. Only the develop ment of Shaughnessy's ${ }^{[13]}$ aqueous phase cross coupling re actions using the water soluble $\mathrm{P}\left(m \mathrm{C}_{6} \mathrm{H}_{4} \mathrm{SO}_{3} \mathrm{Na}\right)_{3}$ (TPPTS) ligand enabled efficient direct modification of nucleosides. We have applied this aqueous methodology to the synthesis of adenosine phenylalanine conjugates ${ }^{[16]}$ and diverse aryl purine bases ${ }^{[17]}$ through Suzuki Miyaura cross coupling. Re cently, the methodology has been extended to reactions of free adenosine monophosphates and to very labile adeno sine triphosphates. ${ }^{[12]}$
Treatment of 8 bromo $2^{\prime}$ deoxyadenosine (1a) with 4 bor onophenylalanine proceeded very smoothly to give conju gate $\mathbf{6}$ in good yield after RP HPLC isolation (Scheme 1). ${ }^{[12]}$ A major problem with the cross coupling reactions of dNTPs was the hydrolysis of triphosphates during the course of the reaction, so the reaction conditions had to be opti mized to shorten the reaction times. The reaction with 8 bromo dATP (1) b) required a higher reaction temperature $\left(125^{\circ} \mathrm{C}\right)$ and the use of $\mathrm{Cs}_{2} \mathrm{CO}_{3}$ (Scheme 1) to reach comple tion within $20 \mathrm{~min}$. The product $\mathbf{A 1}$ was also isolated by RP HPLC in good yield (Table 1 , entry 4). ${ }^{[12]}$

In order to extend a scope of this methodology to other nucleosides and nucleoside triphosphates directly applicable to DNA polymerase incorporation, we investigated the aqueous phase Suzuki Miyaura reactions of 7 deaza 2' deoxy 7 iodoadenosine (2a) and the corresponding triphos phate $\mathbf{2} \mathbf{b}$, as well as those of $2^{\prime}$ deoxy 5 iodouridine (3a) and its triphosphate $\mathbf{3 b}$ with boronophenylalanine $\mathbf{4}$ (Scheme 1). Both the 7 substituted 7 deazapurine dNTPs ${ }^{[5]}$ and the 5 substituted pyrimidine $\left.{ }^{[4} 10\right]$ dNTPs are known to be tolerated as substrates by some DNA polymerases and to be incorporated into DNA. The reactions of the model halo nucleosides $2 \mathbf{a}$ and $3 \mathbf{a}$ proceeded smoothly at $100^{\circ} \mathrm{C}$ in the presence of $\mathrm{Na}_{2} \mathrm{CO}_{3}$ base to give the desired products 7 and 8, respectively, in even higher yields than obtained with 8 substituted adenosine $\mathbf{6}$ (Table 1, entries 2 and 3).

The corresponding reactions of boronic acid 4 with dNTPs $\mathbf{2 b}$ and $\mathbf{3 b}$ were also carried out, at a slightly higher temperature $\left(110^{\circ} \mathrm{C}\right)$ and in the presence of $\mathrm{Cs}_{2} \mathrm{CO}_{3}$ base, to give the phenylalanine dNTPs conjugates $\mathbf{A 3}$ and $\mathbf{T 1}$ in good preparative yields (Table 1, entries 5 and 6) after HPLC isolation.
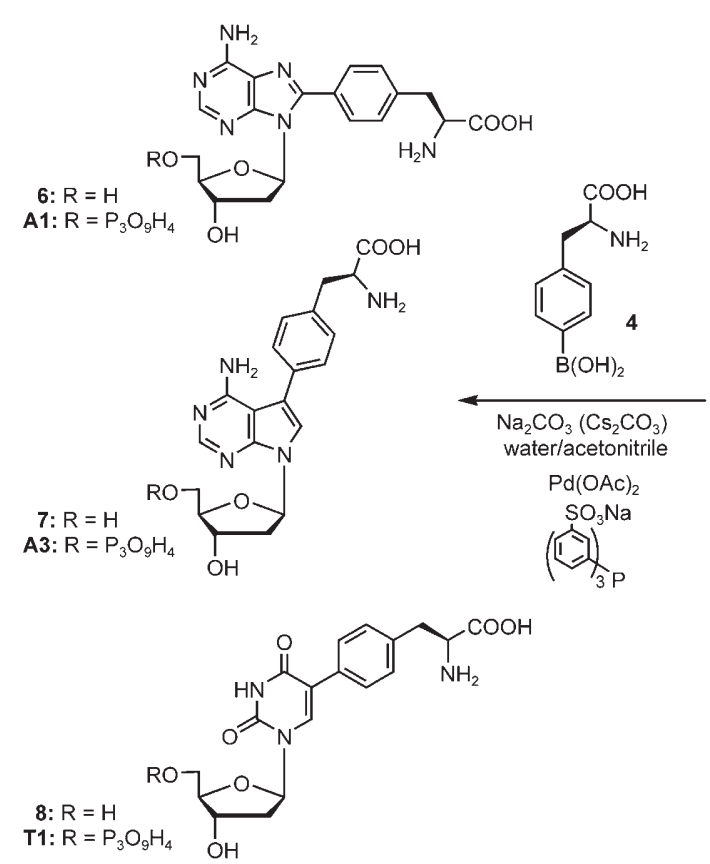

Scheme 1. Synthesis of modified nucleosides and dNTPs.

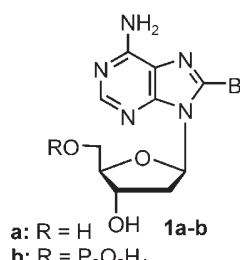

a: $\mathrm{R}=\mathrm{P}_{3} \mathrm{O}_{9} \mathrm{H}_{4}$
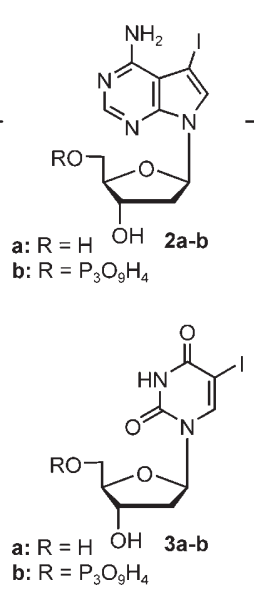
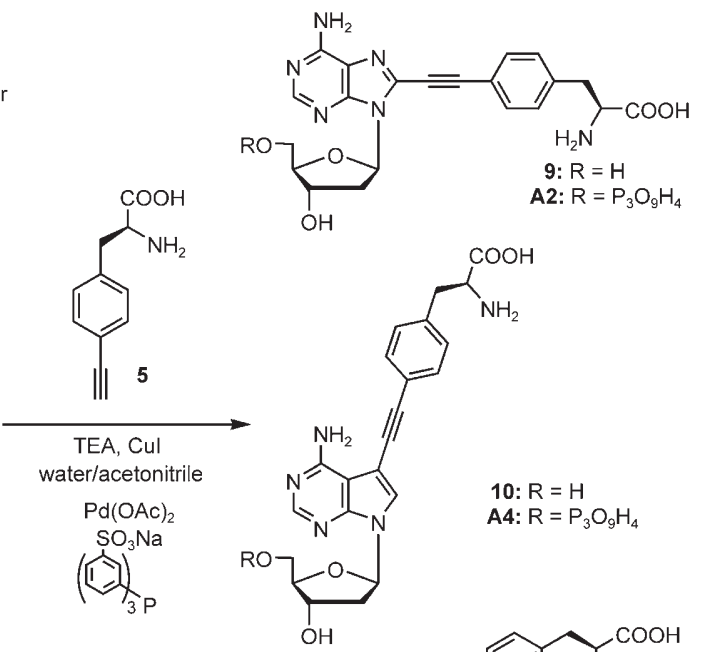

10: $\mathrm{R}=\mathrm{H}$

A4: $\mathrm{R}=\mathrm{P}_{3} \mathrm{O}_{9} \mathrm{H}_{4}$

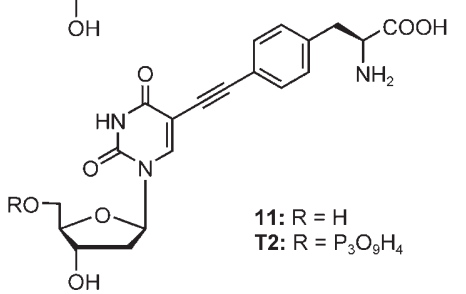


Table 1. Synthesis of modified nucleosides and dNTPs by cross coupling reactions.

\begin{tabular}{|c|c|c|c|c|c|c|}
\hline Entry & $\begin{array}{c}\mathrm{dN} / \\
\mathrm{dNTP}\end{array}$ & $\mathrm{AA}^{[\mathrm{a}]}$ & Additive & $\begin{array}{l}T, \text { reaction } \\
\text { time }\end{array}$ & Product & $\begin{array}{l}\text { Yield } \\
{[\%]}\end{array}$ \\
\hline 1 & $1 \mathbf{a}$ & 4 & $\mathrm{Na}_{2} \mathrm{CO}_{3}$ & $90^{\circ} \mathrm{C}, 2 \mathrm{~h}$ & 6 & 75 \\
\hline 2 & $2 \mathbf{a}$ & 4 & $\mathrm{Na}_{2} \mathrm{CO}_{3}$ & $100^{\circ} \mathrm{C}, 1 \mathrm{~h}$ & 7 & 89 \\
\hline 3 & $3 \mathbf{a}$ & 4 & $\mathrm{Na}_{2} \mathrm{CO}_{3}$ & $100^{\circ} \mathrm{C}, 1.5 \mathrm{~h}$ & 8 & 78 \\
\hline 4 & $1 \mathrm{~b}$ & 4 & $\mathrm{Cs}_{2} \mathrm{CO}_{3}$ & $125^{\circ} \mathrm{C}, 20 \mathrm{~min}$ & $\mathbf{A 1}$ & 55 \\
\hline 5 & $2 \mathbf{b}$ & 4 & $\mathrm{Cs}_{2} \mathrm{CO}_{3}$ & $110^{\circ} \mathrm{C}, 30 \mathrm{~min}$ & $\mathbf{A 3}$ & 66 \\
\hline 6 & $3 \mathbf{b}$ & 4 & $\mathrm{Cs}_{2} \mathrm{CO}_{3}$ & $110^{\circ} \mathrm{C}, 30 \mathrm{~min}$ & T1 & 56 \\
\hline 7 & $1 \mathbf{a}$ & 5 & $\begin{array}{l}\text { CuI, } \\
\text { TEA }\end{array}$ & $60^{\circ} \mathrm{C}, 55 \mathrm{~min}$ & 9 & 61 \\
\hline 8 & $2 \mathbf{a}$ & 5 & $\begin{array}{l}\text { CuI, } \\
\text { TEA }\end{array}$ & $60^{\circ} \mathrm{C}, 50 \mathrm{~min}$ & 10 & 94 \\
\hline 9 & $3 \mathbf{a}$ & 5 & $\begin{array}{l}\text { CuI, } \\
\text { TEA }\end{array}$ & $60^{\circ} \mathrm{C}, 45 \mathrm{~min}$ & 11 & 70 \\
\hline 10 & $1 \mathrm{~b}$ & 5 & $\begin{array}{l}\text { CuI, } \\
\text { TEA }\end{array}$ & $60^{\circ} \mathrm{C}, 1 \mathrm{~h}$ & A2 & 61 \\
\hline 11 & $2 \mathbf{b}$ & 5 & $\begin{array}{l}\text { CuI, } \\
\text { TEA }\end{array}$ & $60^{\circ} \mathrm{C}, 45 \mathrm{~min}$ & A4 & 67 \\
\hline 12 & $\mathbf{3 b}$ & 5 & $\begin{array}{l}\text { CuI, } \\
\text { TEA }\end{array}$ & $60^{\circ} \mathrm{C}, 30 \mathrm{~min}$ & $\mathbf{T} 2$ & 66 \\
\hline
\end{tabular}

[a] Amino acid reagent.

As well as nucleoside/dNTP phenylalanine conjugates with the amino acid linked directly through a bulky phenyl ene group, we also explored the synthesis of a series of con jugates extended by a less bulky acetylene tether (products 9 11, A2, A4, and T2). This type of attachment was de signed as an analogy to the modified dNTPs successfully recognized by DNA polymerases with a "nucleobase acety lene linker functionality" structural pattern. $\left.{ }^{[4} 11\right]$ The extend ed conjugates were prepared by Sonogashira cross coupling reactions of halonucleosides $1 \mathbf{a} \mathbf{3} \mathbf{a}$ and dNTPs $\mathbf{1 b} \mathbf{3 b}$ with 4 (ethynyl)phenylalanine (5; Scheme 1). Analogously with the Suzuki reactions, the Sonogashira reactions were per formed in water/acetonitrile mixtures and with the same water soluble catalytic system $\left(\mathrm{Pd}(\mathrm{OAc})_{2} / \mathrm{TPPTS}\right)$, together with triethylamine (TEA) as a base and $\mathrm{CuI}$ as an additive. Reactions both with nucleosides and with dNTPs proceeded smoothly at $60^{\circ} \mathrm{C}$ to give the corresponding products $9 \mathbf{1 1}$, $\mathbf{A 2}, \mathbf{A 4}$, and $\mathbf{T 2}$ in very good yields (Table 1, entries 7 12) within $30 \mathrm{~min}$ to $1 \mathrm{~h}$.

Incorporation of modified dNTPs by DNA polymerases: All the novel functionalized dATPs A1 A4 and dTTPs T1 and T2 were examined as substrates for several types of thermo stable DNA polymerases in primer extension experiments and polymerase chain reactions (PCRs). In the initial model PCR experiments, we tested Thermus aquaticus (Taq), Ther mococcus litoralis (Vent $\left(\right.$ exo $\left.\left.^{-}\right)\right)$, and Pyrococcus woesei $(P w o)$ DNA polymerases, which had been shown ${ }^{[5]}$ to incor porate a broad spectrum of modified dNTPs efficiently. Since Pwo DNA polymerase showed the most promising re sults, further optimization was performed only with this enzyme. The best conditions found involved the addition of $2 \%$ DMSO, higher enzyme concentrations, and increasing of the denaturing temperature $\left(98^{\circ} \mathrm{C}\right)$ within PCR cycling (see below).
The formation of functionalized DNA in primer extension experiments with $P$ wo DNA polymerase was studied with a 35 mer template in the presence of ${ }^{32} \mathrm{P}$ labeled $25 \mathrm{mer}$ primer, the modified dATP (A1 A4) or dTTP (T1 or T2), and three additional natural dNTPs. The reaction products derived from primer extension were tracked by denaturing polyacrylamide gel electrophoresis (PAGE) and phosphori maging analysis (Figure 1). No incorporation of A1 and $\mathbf{A 2}$

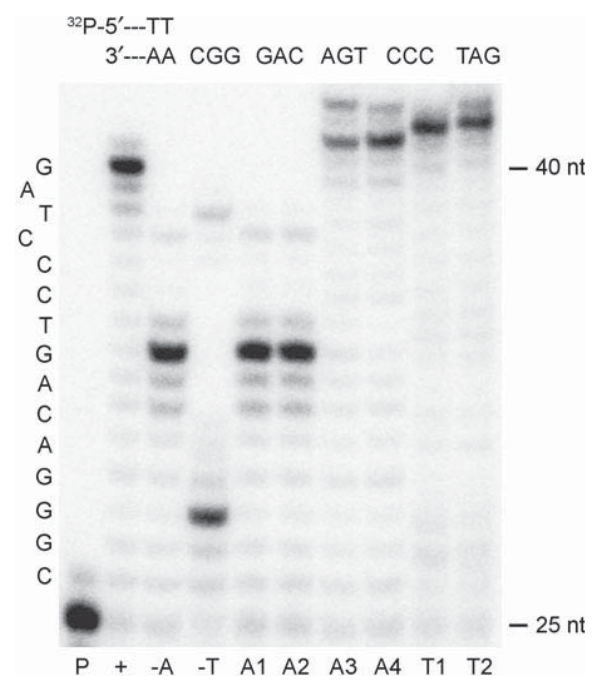

Figure 1. Primer extension with $P$ wo DNA polymerase. $5{ }^{32} \mathrm{P}$ end labeled primer template (sequences as indicated in the figure) was incubated with different combinations of natural and functionalized dNTPs. P: Primer; +: natural dNTPs; -A: dTTP, dCTP, dGTP; -T: dATP, dCTP, dGTP; A1: A1, dTTP, dCTP, dGTP; A2: A2, dTTP, dCTP, dGTP; A3: A3, dTTP, dCTP, dGTP; A4: A4, dTTP, dCTP, dGTP; T1; T1, dATP, dCTP, dGTP; T2: T2, dATP, dCTP, dGTP.

was observed in these experiments, but the other two modi fied dATPs derived from 7 deazaadenine (A3 and $\mathbf{A 4})$, as well as both modified dTTPs ( $\mathbf{T} 1$ and $\mathbf{T 2}$ ), were incorporat ed, resulting in full length reaction products (Figure 1). However, the formation of an additional, more slowly mi grating band was observed to a varied extent in cases in which the primer was fully extended. $3^{\prime} 5^{\prime}$ exonuclease defi cient DNA polymerases are known to add an additional nu cleotide in an untemplated fashion under certain circum stances, resulting in an extra band after PAGE analysis. ${ }^{[18]}$ Since the generated DNA is highly modified, the $3^{\prime} 5^{\prime}$ exo nuclease of $P$ wo DNA polymerase might be functioning less efficiently, which might well be the cause of the observed effect. Alternatively, the effects might arise from secondary structures with different stability or from higher aggregates that cannot be resolved under the conditions applied in stan dard denaturing PAGE as discussed previously. ${ }^{[5 a]}$

These promising results prompted us to attempt simulta neous incorporation of modified adenine and thymine into one DNA strand. The primer extension experiments were performed with combinations of functionalized dATP and dTTP (A3T1, A4T1, A3 T2, and A4T2) in the presence of 
natural dGTP and dCTP (Figure 2). All four combinations of modified A and Twere successfully incorporated.

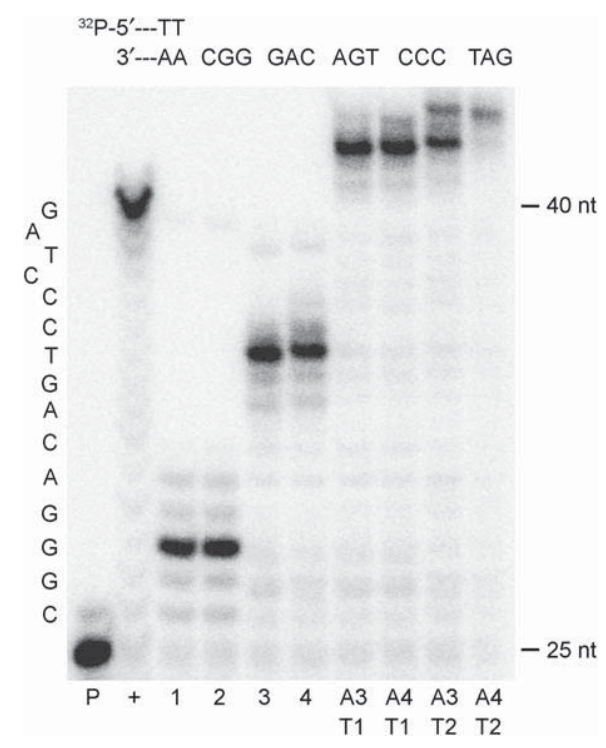

Figure 2. Primer extension in the presence of two functionalized dNTPs. $5{ }^{32} \mathrm{P}$ end labeled primer template (sequences as indicated in the figure) were incubated with double substituted combinations of functionalized dNTPs. P: Radiolabeled Primer; +: natural dNTPs; 1 : A3, dCTP, dGTP; 2; A4, dCTP, dGTP; 3: T1, dCTP, dGTP; 4: T2, dCTP, dGTP; A3 T1: A3, T1, dCTP, dGTP; A4T1: A4, T1, dCTP, dGTP; A3T2: A3, T2, dCTP, dGTP; A4T2: A4, T2, dCTP, dGTP.

Next, we performed PCR experiments with a 98 mer tem plate and 20 and 25 mer primers in the presence of $P$ wo DNA polymerase (Scheme 2). The formation of functional ized DNA after 30 PCR cycles in the presence of primers, modified dATP (A1 A4) or dTTP (T1 or T2), and three ad ditional natural dNTPs was analyzed by agarose gel electro phoresis. The first experiment involved the testing of each functionalized dNTP (A1 A4, T1 or T2) in mixtures with natural dGTP, dCTP, and dTTP (for A1 A4) or dGTP, dCTP and dATP (for T1 or T2). The results were consistent with those obtained in the primer extension experiments (Figure 3). PCR in the presence of the 8 substituted adeno sines A1 and A2 did not yield any significant amounts of DNA product, while PCR was successful in the presence of the 7 substituted 7 deazaadenines (A3 and A4) and the modified thymines (T1 and $\mathbf{T} 2$ ), although the band for the A4 product was faint. The substrate most efficiently used by the DNA polymerase was the acetylene linked thymine T2, which was also the only modified dNTP efficiently incorpo rated by Vent (exo ${ }^{-}$) DNA polymerase in our hands (not shown).

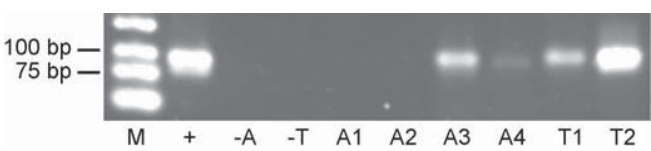

Figure 3. Generation by PCR of double stranded DNA incorporating functionalized dNTPs. The amplified DNA has a length of $98 \mathrm{nt}$. M: Marker; +: natural dNTPs; -A: dTTP, dGTP, dCTP; -T: dATP, dGTP, dTTP; A1: A1, dTTP, dGTP, dTTP; A2: A2, dTTP, dGTP, dCTP; A3: A3, dTTP, dGTP, dCTP; A4: A4, dTTP, dGTP, dCTP; T1: T1, dATP, dGTP, dCTP; T2: T2, dATP, dGTP, dCTP.

The ability of Pwo DNA polymerase to substitute two natural dNTPs with their modified counterparts in PCR was also examined. Efforts to employ combinations of $\mathbf{A 3}$ and A4 with $\mathbf{T 1}$ were unsuccessful (not shown), but on the other hand, combinations of the two functionalized 7 deazaadeno sine triphosphates $\mathbf{A 3}$ and A4 with T2 were successful, re sulting in DNA duplexes with a very high density of modifi cation (Figure 4).

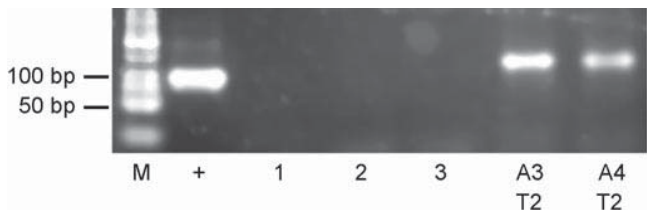

Figure 4. Generation of functionalized DNA duplexes in the presence of two modified dNTPs. M: Marker; +: natural dNTPs; 1: A3, dCTP, dGTP; 2: A4, dCTP, dGTP; 3: T2, dCTP, dGTP; A3 T2: A3, T2, dCTP, dGTP; A4T2: A4, T2, dCTP, dGTP.

Finally, a preparative scale PCR experiment with the most efficiently incorporated dNTP T2 was performed and the resulting DNA duplex was characterized by thermal de naturating studies (melting temperature measurements) and CD spectroscopy. The melting temperature of the function alized DNA containing $43 \mathbf{T 2}$ modifications was found to be $80^{\circ} \mathrm{C}$, which is almost the same as that of the natural 98 mer duplex $\left(81^{\circ} \mathrm{C}\right)$. The $\mathrm{CD}$ spectrum of this $\mathbf{T} 2$ containing duplex DNA shows no significant deviation from the common B form signatures of the natural duplex (Figure 5). This shows that the major groove modification of DNA by phenylalanine moieties does not significantly destabilize the duplex.

\section{Conclusion}

An efficient single step functionalization of halogenated nu cleoside triphosphates through aqueous phase Suzuki 


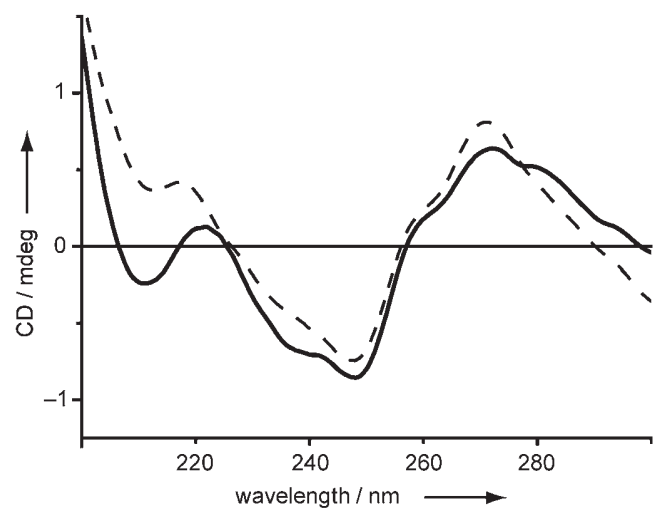

Figure 5. CD spectra of T2 modified and natural 98 mer duplex. Solid line: unmodified DNA. Dashed line: duplex containing T2.

Miyaura or Sonogashira cross coupling reactions with amino acid based boronic acids or acetylenes has been developed. This method does not require protection of any of the reac tion components and allows expeditious and simple modifi cations of dNTPs with functionalized aryl or alkynyl groups. In our view, this approach is more practical than the alterna tive phosphorylation of functionalized nucleosides used by other groups. ${ }^{[4]}$ The methodology was used for the synthe sis of six types of dNTPs: 8 substituted dATP, 7 substituted 7 deaza dATP, and 5 substituted dUTP bearing phenylala nine moieties linked either directly through a phenyl ring or through an acetylene tether. All the novel dNTPs were tested as substrates for DNA polymerases in the enzymatic construction of functionalized DNA by primer extension and PCR. Pwo DNA polymerase was found to be the best suited enzyme, capable of incorporation of 7 substituted 7 deaza dATP (A3 and A4) and 5 substituted dUTP (T1 and T2), while 8 substituted dATP derivatives (A1 and A2) were not suitable as substrates, in accordance with reports by Famulok and colleagues. Other DNA polymerases were not effective, with the sole exception of Vent (exo-) DNA polymerase, which incorporated $\mathbf{T} 2$ in PCR experiment. Si multaneous incorporation of all four combinations of modi fied A (A3 or A4) and T (T1 or T2) was efficient in primer extension, while in PCR only A3T2 and A4T2 combina tions were successful. A 98 mer DNA duplex containing T2 modifications was characterized by $T_{\mathrm{m}}$ and $\mathrm{CD}$ spectroscopy and showed no significant deviation from the stability and B form DNA features of the natural duplex.

The combination of the aqueous phase cross coupling re actions of halogenated dNTPs with enzymatic incorporation by DNA polymerases is a novel and efficient two step ap proach for the construction of functionalized DNA. Since the modification is introduced in the last chemical step, just prior to enzymatic incorporation, this methodology is well suited for the generation of a series of diverse modified nu cleic acids. Primer extension can be efficiently used for in corporation of several modifications to specific positions in a single DNA strand, while PCR is suitable for construction and amplification of DNA duplexes with high degrees of modification. Further studies are currently focussing on ex tension of the scope of the cross coupling reactions of dNTPs to other types of reagents and functional groups and on construction of DNA bearing other biorelevant and/or useful functions.

\section{Experimental Section}

NMR spectra were measured on Bruker AMX $3400\left(400 \mathrm{MHz}\right.$ for ${ }^{1} \mathrm{H}$ and $100.6 \mathrm{MHz}$ for ${ }^{13} \mathrm{C}$ nuclei) and Bruker DRX $500\left(500 \mathrm{MHz}\right.$ for ${ }^{1} \mathrm{H}$ and $125.8 \mathrm{MHz}$ for ${ }^{13} \mathrm{C}$ ) instruments in $\mathrm{D}_{2} \mathrm{O}$ (referenced to dioxane as in ternal standard, $\delta_{\mathrm{H}}=3.75 \mathrm{ppm}, \delta_{\mathrm{C}}=67.19 \mathrm{ppm}$ ) or in $\left[\mathrm{D}_{6}\right] \mathrm{DMSO}$ (refer enced to the residual solvent signal). Chemical shifts are given in ppm $(\delta$ scale), coupling constants $(J)$ in Hz. Complete assignment of all NMR signals was achieved by use of a combination of H,H COSY, H,C HSQC, and $\mathrm{H}, \mathrm{C}$ HMBC experiments. Mass spectra were measured on a ZAB EQ (VG Analytical) spectrometer by FAB (ionization by Xe, accelerat ing voltage $8 \mathrm{kV}$, glycerol+thioglycerol matrix) or on an LCQ classic (Thermo Finnigan) spectrometer by $\mathrm{ES}^{-}$. Optical rotations were mea sured at $25^{\circ} \mathrm{C}$ on an Autopol IV (Rudolph Research Analytical) polarim

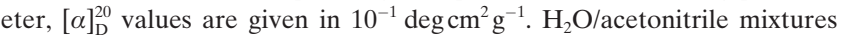
were degassed in vacuo and stored under argon. Preparative HPLC sepa rations were performed on a column packed with $10 \mu \mathrm{m}$ C18 reversed phase (Phenomenex, Luna C18(2)). Known starting compounds were either purchased (3a from Berry and $\mathbf{4}$ from Frontier Scientific) or pre pared by literature procedures: $\mathbf{1 a},{ }^{[19]} \mathbf{1 b},{ }^{[20]} \mathbf{2 a},{ }^{[21]}$ and $\mathbf{3 b}{ }^{[22]}$ Synthesis and characterization data for compounds $\mathbf{6}$ and $\mathbf{A 1}$ were reported previ ously. ${ }^{[12]}$

(S)-4-Ethynylphenylalanine (5): A water/acetonitrile mixture 2:1 (30 mL) was added through a septum to an argon purged vial containing $(S) 4$ io dophenylalanine $(730 \mathrm{mg}, 2.5 \mathrm{mmol})$, trimethylsilylacetylene $(2.5 \mathrm{~mL}$, $17.7 \mathrm{mmol}), \mathrm{Pd}(\mathrm{OAc})_{2}(22.4 \mathrm{mg}, 0.1 \mathrm{mmol})$, TPPTS $(228 \mathrm{mg}, 0.4 \mathrm{mmol})$, $\mathrm{CuI}(48 \mathrm{mg}, 0.25 \mathrm{mmol})$, and TEA $(1.2 \mathrm{~mL}, 8.6 \mathrm{mmol})$. The mixture was stirred at ambient temperature for $20 \mathrm{~h}$. Products were isolated from the crude reaction mixture (after filtration) by HPLC on a $\mathrm{C} 18$ column with use of a linear gradient of $0.3 \% \mathrm{AcOH}$ in $\mathrm{H}_{2} \mathrm{O}$ to $0.3 \% \mathrm{AcOH}$ in $\mathrm{MeOH}$ as eluent. Several co distillations with water followed by freeze drying from water gave 5 (118 $\mathrm{mg}, 25 \%)$ as white solid that was directly used in the following step. ${ }^{1} \mathrm{HNMR}\left(500 \mathrm{MHz}, \mathrm{D}_{2} \mathrm{O}, \quad \operatorname{ref}_{\text {dioxane }}=\right.$ $3.75 \mathrm{ppm}): \delta=3.13\left(\mathrm{dd}, J_{\text {gem }}=14.6, J_{\text {vic }}=7.9 \mathrm{~Hz}, 1 \mathrm{H} ; \mathrm{bCH}_{2}\right), 3.28(\mathrm{dd}$, $\left.J_{\text {gem }}=14.6, J_{\text {vic }}=5.4 \mathrm{~Hz}, 1 \mathrm{H} ; \mathrm{aCH}_{2}\right), 3.52(\mathrm{~s}, 1 \mathrm{H} ; \mathrm{HC}=\mathrm{C}), 3.98\left(\mathrm{dd}, J_{\text {vic }}=\right.$ 7.9, $5.4 \mathrm{~Hz}, 1 \mathrm{H} ; \mathrm{CH}), 7.30(\mathrm{~m}, 2 \mathrm{H} ; \mathrm{H} m$ phenylene $), 7.54 \mathrm{ppm}(\mathrm{m}, 2 \mathrm{H}$; $\mathrm{H} o$ phenylene); ${ }^{13} \mathrm{C}$ NMR $\left(125.8 \mathrm{MHz}, \mathrm{D}_{2} \mathrm{O}, \operatorname{ref}_{\text {dioxane }}=69.3 \mathrm{ppm}\right): \delta=$ $38.97\left(\mathrm{CH}_{2}\right), 58.50(\mathrm{CH}), 81.16(\mathrm{C}=\mathrm{CH}), 86.28(\mathrm{C}=\mathrm{CH}), 123.36(\mathrm{C} i$ phen ylene), 132.23 ( $\mathrm{CH} m$ phenylene), 135.35 ( $\mathrm{CH} o$ phenylene), 139.04 (C $p$ phenylene), $178.58 \mathrm{ppm}(\mathrm{CO})$.

9-(2-Deoxy- $\beta$-D-erythro-pentofuranosyl)-7-iodo-7-deazapurine $\quad 5$ - $O$-triphosphate (2b): Nucleoside 2 a $(113 \mathrm{mg}, 0.3 \mathrm{mmol})$ was suspended in tri methyl phosphate $(0.75 \mathrm{~mL})$ at $0{ }^{\circ} \mathrm{C}$ and $\mathrm{POCl}_{3}(35 \mu \mathrm{L}, 0.36 \mathrm{mmol})$ was added. After the mixture had been stirred at $0^{\circ} \mathrm{C}$ for $45 \mathrm{~min}$, an ice cooled solution of $\left(\mathrm{NHBu}_{3}\right)_{2} \mathrm{H}_{2} \mathrm{P}_{2} \mathrm{O}_{7}(820 \mathrm{mg}, 1.5 \mathrm{mmol})$ and $\mathrm{Bu}_{3} \mathrm{~N}$ $(0.3 \mathrm{~mL}, 1.25 \mathrm{mmol})$ in dry DMF $(3 \mathrm{~mL})$ was added and the mixture was stirred at $0^{\circ} \mathrm{C}$ for another $30 \mathrm{~min}$. The reaction was then quenched by ad dition of aqueous TEAB $(1 \mathrm{~m}, 2 \mathrm{~mL})$, the solvents were evaporated in vacuo, and the residue was co distilled three times with water. The prod uct was isolated on a DEAE Sephadex column $(150 \mathrm{~mL})$ with elution with a gradient of 0 to $1.2 \mathrm{M}$ TEAB, evaporated, co distilled with water $(3 \times)$, and lyophilized to yield a white powder $(110 \mathrm{mg}, 38 \%) .{ }^{1} \mathrm{H}$ NMR $\left(400 \mathrm{MHz}, \quad \mathrm{D}_{2} \mathrm{O}+\mathrm{Et}_{3} \mathrm{~N}, \quad \operatorname{ref}_{\text {dioxane }}=3.75 \mathrm{ppm}\right): \delta=1.25 \quad\left(\mathrm{t}, \quad J_{\text {vic }}=7.3 \mathrm{~Hz}\right.$, $\left.27 \mathrm{H} ; \mathrm{CH}_{3} \mathrm{CH}_{2} \mathrm{~N}\right), 2.51\left(\mathrm{ddd}, J_{\mathrm{gem}}=14.0, J_{2^{\prime} \mathrm{b}, 1^{\prime}}=6.3, J_{2^{\prime} \mathrm{b}, 3^{\prime}}=3.6 \mathrm{~Hz}, 1 \mathrm{H} ; \mathrm{H}\right.$ $\left.2^{\prime} \mathrm{b}\right), 2.69\left(\mathrm{ddd}, J_{\mathrm{gem}}=14.0, J_{2^{\prime} \mathrm{a}, 1^{\prime}}=7.6, J_{2^{\prime} \mathrm{a}, 3^{\prime}}=6.3 \mathrm{~Hz}, 1 \mathrm{H} ; \mathrm{H} 2^{\prime} \mathrm{a}\right), 3.15$ (q, $\left.J_{\text {vic }}=7.3 \mathrm{~Hz}, 18 \mathrm{H} ; \mathrm{CH}_{3} \mathrm{CH}_{2} \mathrm{~N}\right), 4.074 .23\left(\mathrm{~m}, 3 \mathrm{H} ; \mathrm{H} 4^{\prime}\right.$ and $\left.\mathrm{H}^{\prime}\right), 4.76$ $\left(\mathrm{dt}, J_{3^{\prime}, 2^{\prime}}=6.3,3.6, J_{3^{\prime}, 4^{\prime}}=3.5 \mathrm{~Hz}, 1 \mathrm{H} ; \mathrm{H}^{\prime}\right), 6.52\left(\mathrm{t}, J_{1^{\prime} 2^{\prime}}=7.6,6.3 \mathrm{~Hz}, 1 \mathrm{H}\right.$; H $\left.1^{\prime}\right), 7.64$ (s, $\left.1 \mathrm{H} ; \mathrm{H} 8\right), 8.01 \mathrm{ppm}(\mathrm{s}, 1 \mathrm{H} ; \mathrm{H} 2) ;{ }^{13} \mathrm{C} \mathrm{NMR}(100.6 \mathrm{MHz}$, $\mathrm{D}_{2} \mathrm{O}+\mathrm{Et}_{3} \mathrm{~N}$, ref dioxane $\left.=69.3 \mathrm{ppm}\right): \delta=10.95\left(\mathrm{CH}_{3} \mathrm{CH}_{2} \mathrm{~N}\right), 41.05\left(\mathrm{CH}_{2} 2^{\prime}\right)$, $49.26\left(\mathrm{CH}_{3} \mathrm{CH}_{2} \mathrm{~N}\right), 54.49(\mathrm{C} 7), 68.15\left(\mathrm{~d}, J_{\mathrm{C}, \mathrm{P}}=5 \mathrm{~Hz} ; \mathrm{CH}_{2} 5^{\prime}\right), 73.56(\mathrm{CH}$ 
$\left.3^{\prime}\right), 85.35\left(\mathrm{CH}^{\prime}\right), 87.94\left(\mathrm{~d}, J_{\mathrm{C}, \mathrm{P}}=9 \mathrm{~Hz} ; \mathrm{CH} 4^{\prime}\right), 106.37(\mathrm{C} \mathrm{5}), 129.74(\mathrm{CH}$ 8), 151.67 (C 4), 154.21 ( $\mathrm{CH} 2), 159.56 \mathrm{ppm}$ (C 6); ${ }^{31} \mathrm{P}\left({ }^{1} \mathrm{H}\right.$ dec.) NMR $\left(162 \mathrm{MHz}, \mathrm{D}_{2} \mathrm{O}+\mathrm{Et}_{3} \mathrm{~N}, \mathrm{ref}_{\mathrm{H}_{3} \mathrm{PO}_{4}}=0 \mathrm{ppm}\right): \delta=-22.65(\mathrm{t}, J=20.9,19.8 \mathrm{~Hz}$; $\left.\mathrm{P}_{\beta}\right),-11.36\left(\mathrm{~d}, J=19.8 \mathrm{~Hz} ; \mathrm{P}_{\alpha}\right),-6.54 \mathrm{ppm}\left(\mathrm{d}, J=20.9 \mathrm{~Hz}, \mathrm{P}_{\gamma}\right) ; \mathrm{MS}$ $\left(\mathrm{ES}^{-}\right): m / z: 615$ (100) $[M-1]^{-}, 517$ (75) $\left[M-\mathrm{PO}_{3} \mathrm{H}_{2}-1\right]^{-}$; HRMS (ES ${ }^{-}$): $m / z$ : calcd for $\mathrm{C}_{11} \mathrm{H}_{15} \mathrm{~N}_{4} \mathrm{O}_{12} \mathrm{P}_{3} \mathrm{I}$ : 614.8944; found: 614.8952 .

Synthesis of modified nucleosides-Suzuki-Miyaura cross-couplingGeneral Procedure A: A water/acetonitrile mixture 2:1 (1.2 $\mathrm{mL})$ was added through a septum to an argon purged vial containing halogenated nucleosides 1a 3a $(0.1 \mathrm{mmol})$, boronic acid $4(27 \mathrm{mg}, 0.13 \mathrm{mmol}), \mathrm{Pd}$ $(\mathrm{OAc})_{2} \quad(1.12 \mathrm{mg}, \quad 0.005 \mathrm{mmol})$, TPPTS $(14.2 \mathrm{mg}, 0.025 \mathrm{mmol})$, and $\mathrm{Na}_{2} \mathrm{CO}_{3}(32 \mathrm{mg}, 0.3 \mathrm{mmol}$ ). The mixture was stirred with heating (for temperature and reaction time see Table 1 ). The products were isolated from the crude reaction mixture by HPLC on a C18 column with use of a linear gradient of $0.3 \% \mathrm{AcOH}$ in $\mathrm{H}_{2} \mathrm{O}$ to $0.3 \% \mathrm{AcOH}$ in $\mathrm{MeOH}$ as eluent. Several co distillations with water, followed by freeze drying from water, gave the products as white solids.

Synthesis of modified nucleosides-Sonogashira cross-coupling-General Procedure B : A water/acetonitrile mixture $(2: 1,1.2 \mathrm{~mL})$ was added through a septum to an argon purged vial containing halogenated nucleo sides 1a 3a $(0.1 \mathrm{mmol})$, acetylene 5 (28 mg, $0.15 \mathrm{mmol}), \mathrm{Pd}(\mathrm{OAc})_{2}$ (1.12 mg, $\quad 0.005 \mathrm{mmol}), \quad$ TPPTS $(11.4 \mathrm{mg}, \quad 0.02 \mathrm{mmol}), \quad \mathrm{CuI} \quad(2 \mathrm{mg}$, $0.1 \mathrm{mmol})$, and TEA $(80 \mu \mathrm{L}, 0.57 \mathrm{mmol})$. The mixture was stirred at $60^{\circ} \mathrm{C}$ (for reaction time see Table 1 ). Products were isolated from the crude reaction mixture by HPLC on a $\mathrm{C} 18$ column with use of a linear gradient of $0.3 \% \mathrm{AcOH}$ in $\mathrm{H}_{2} \mathrm{O}$ to $0.3 \% \mathrm{AcOH}$ in $\mathrm{MeOH}$ as eluent. Several co distillations with water, followed by freeze drying from water, gave the products as white solids.

Synthesis of modified dNTPs-Suzuki-Miyaura cross-coupling-General Procedure C: A water/acetonitrile mixture $(2: 1,0.5 \mathrm{~mL})$ was added through a septum to an argon purged vial containing the halogenated dNTP 1 b 3 b $(0.05 \mathrm{mmol})$, boronic acid $4(20 \mathrm{mg}, 0.1 \mathrm{mmol})$, and $\mathrm{Cs}_{2} \mathrm{CO}_{3}$ $(81 \mathrm{mg}, 0.25 \mathrm{mmol})$. After the solids had dissolved, a solution of $\mathrm{Pd}$ $(\mathrm{OAc})_{2}(1.12 \mathrm{mg}, 0.005 \mathrm{mmol})$ and TPPTS (14.2 $\left.\mathrm{mg}, 0.025 \mathrm{mmol}\right)$ in water/acetonitrile $(2: 1,0.3 \mathrm{~mL})$ was added and the mixture was stirred with heating (for temperature and reaction time see Table 1). The prod ucts were isolated from the crude reaction mixture by HPLC on a C18 column with use of a linear gradient of $0.1 \mathrm{M}$ TEAB (triethylammo nium bicarbonate) in $\mathrm{H}_{2} \mathrm{O}$ to $0.1 \mathrm{~m}$ TEAB in $\mathrm{H}_{2} \mathrm{O} / \mathrm{MeOH} 1: 1$ as eluent. Several co distillations with water, followed by freeze drying from water, gave the products as white solids.

Synthesis of modified dNTPs-Sonogashira cross-coupling-General Procedure D: A water/acetonitrile mixture $(2: 1,0.5 \mathrm{~mL})$ was added through a septum to an argon purged vial containing the halo dNTP 1b 3b $(0.05 \mathrm{mmol})$, acetylene 5 (19 $\mathrm{mg}, 0.1 \mathrm{mmol})$, CuI $(2 \mathrm{mg}, 0.01 \mathrm{mmol})$, and TEA $(50 \mu \mathrm{L}, 0.36 \mathrm{mmol})$. After the solids had dissolved, a solution of $\mathrm{Pd}(\mathrm{OAc})_{2}(1.12 \mathrm{mg}, 0.005 \mathrm{mmol})$ and TPPTS $(14.2 \mathrm{mg}, 0.025 \mathrm{mmol})$ in water/acetonitrile $(2: 1,0.3 \mathrm{~mL})$ was added and the mixture was stirred with heating at $60^{\circ} \mathrm{C}$ (for reaction time see Table 1 ). The products were isolated from the crude reaction mixture by HPLC on a C18 column with use of a linear gradient of $0.1 \mathrm{~m}$ TEAB in $\mathrm{H}_{2} \mathrm{O}$ to $0.1 \mathrm{~m}$ TEAB in $\mathrm{H}_{2} \mathrm{O}$ / $\mathrm{MeOH}(1: 1)$ as eluent. Several co distillations with water, followed by freeze drying from water, gave the products as white solids.

(S)-2-Amino-3-(4-\{[6-amino-9-(2-deoxy- $\beta$-D-erythro-pentofuranosyl)purin-8-yl] ethynyl\}phenyl)propanoic acid (9): This compound was pre pared by Method B from 1a, yield $61 \%$. $[\alpha]_{\mathrm{D}}^{20}=-37.7(c=1.60, \mathrm{DMSO})$; ${ }^{1} \mathrm{H}$ NMR (400 MHz, [D $]$ DMSO): $\delta=2.26$ (ddd, $J_{\mathrm{gem}}=13.2, J_{2^{\prime} \mathrm{b}, 1^{\prime}}=6.5$, $\left.J_{2 \mathrm{~b} 3^{\prime}}=2.6 \mathrm{~Hz}, 1 \mathrm{H} ; \mathrm{H} 2^{\prime} \mathrm{b}\right), 2.94\left(\mathrm{dd}, J_{\mathrm{gem}}=14.0, J_{\mathrm{vic}}=8.1 \mathrm{~Hz}, 1 \mathrm{H} ; \mathrm{bCH}_{2}\right)$, $3.15\left(\mathrm{ddd}, J_{\mathrm{gem}}=13.2, J_{2^{\prime} \mathrm{a}, 1^{\prime}}=7.9, J_{2^{\prime} \mathrm{a}, 3^{\prime}}=6.2 \mathrm{~Hz}, 1 \mathrm{H} ; \mathrm{H} \mathrm{2} 2^{\prime} \mathrm{a}\right), 3.19$ (dd, $\left.J_{\text {gem }}=14.0, J_{\text {vic }}=4.8 \mathrm{~Hz}, 1 \mathrm{H} ; \mathrm{aCH}_{2}\right), 3.45\left(\mathrm{dd}, J_{\text {vic }}=8.1,4.8 \mathrm{~Hz}, 1 \mathrm{H} ; \mathrm{CH}\right)$, $3.51\left(\mathrm{dd}, J_{\text {gem }}=11.8, J_{5^{\prime} \mathrm{b}, 4^{\prime}}=4.9 \mathrm{~Hz}, 1 \mathrm{H} ; \mathrm{H} 5^{\prime} \mathrm{b}\right), 3.68\left(\mathrm{dd}, J_{\text {gem }}=11.8\right.$, $\left.J_{5^{\prime} \mathrm{a}, 4^{\prime}}=4.4 \mathrm{~Hz}, 1 \mathrm{H} ; \mathrm{H} 5^{\prime} \mathrm{a}\right), 3.91\left(\mathrm{td}, J_{4^{\prime} 5^{\prime}}=4.9,4.4, J_{4^{\prime} 3^{\prime}}=2.9 \mathrm{~Hz}, 1 \mathrm{H} ; \mathrm{H} 4^{\prime}\right)$, $4.51\left(\mathrm{dt}, J_{3^{\prime}, 2^{\prime}}=6.2,2.6, J_{3^{\prime}, 4^{\prime}}=2.9 \mathrm{~Hz}, 1 \mathrm{H} ; \mathrm{H}^{\prime}\right), 5.30$ and $5.50(\mathrm{br}, 2 \mathrm{H}$; OH $\left.3^{\prime}, 5^{\prime}\right), 6.52\left(\mathrm{dd}, J_{1^{\prime} 2^{\prime}}=7.9,6.5 \mathrm{~Hz}, 1 \mathrm{H} ; \mathrm{H} 1^{\prime}\right), 7.40(\mathrm{~m}, 2 \mathrm{H} ; \mathrm{H} m$ phen ylene), $7.58\left(\mathrm{~m}, 4 \mathrm{H} ; \mathrm{NH}_{2}, \mathrm{H} o\right.$ phenylene $), 8.17 \mathrm{ppm}(\mathrm{s}, 1 \mathrm{H} ; \mathrm{H} 2)$; ${ }^{13} \mathrm{C}$ NMR (100.6 MHz，[D $]$ DMSO): $\delta=37.22\left(\mathrm{CH}_{2}\right), 37.96\left(\mathrm{CH}_{2} 2^{\prime}\right)$, $55.48(\mathrm{CH}), 62.39\left(\mathrm{CH}_{2} 5^{\prime}\right), 71.42\left(\mathrm{CH}^{\prime}\right), 82.94(\mathbf{C}=\mathrm{C}$ phenylene $), 85.18$ $\left(\mathrm{CH}^{\prime}\right), 88.45\left(\mathrm{CH}^{\prime}\right), 94.84(\mathrm{C}=\mathbf{C}$ phenylene $), 118.14$ ( $\mathrm{C} i$ phenylene $)$,
119.75 (C 5), 130.34 (CH $m$ phenylene), 132.04 (CH $o$ phenylene), 133.12 (C 8), 140.79 (C p phenylene), 148.80 (C 4), 153.57 (CH 2), 156.24 (C 6), 169.29 ppm (CO); IR (KBr): $\tilde{v}=3392,3172,2212,1643,1602,1401,1338$, 1095, 1058, $796 \mathrm{~cm}^{-1}$; MS (FAB): $m / z: 439$ (100) $[M+1]^{+}$; HRMS (FAB): $m / z$ : calcd for $\mathrm{C}_{21} \mathrm{H}_{23} \mathrm{~N}_{6} \mathrm{O}_{5}$ : 439.1730; found: 439.1721 .

(S)-2-Amino-3-\{4-[6-amino-9-(2-deoxy- $\beta$-D-erythro-pentofuranosyl)-7deazapurin-7-yl]phenyl\}propanoic acid (7): This compound was prepared by Method A from 2 a, yield $89 \%$. $[\alpha]_{\mathrm{D}}^{20}=-19.5\left(c=2.12, \mathrm{H}_{2} \mathrm{O}\right) ;{ }^{1} \mathrm{H}$ NMR $\left(500 \mathrm{MHz}, \quad\left[\mathrm{D}_{6}\right] \mathrm{DMSO}\right): \quad \delta=2.20\left(\mathrm{ddd}, \quad J_{\mathrm{gem}}=13.2, \quad J_{2^{\prime} \mathrm{b}, 1^{\prime}}=6.0, \quad J_{2^{\prime} \mathrm{b}, 3^{\prime}}=\right.$ $\left.2.7 \mathrm{~Hz}, 1 \mathrm{H} ; \mathrm{H} 2^{\prime} \mathrm{b}\right), 2.56\left(\mathrm{ddd}, J_{\mathrm{gem}}=13.2, J_{2^{\prime} \mathrm{a}, 1^{\prime}}=8.3, J_{2^{\prime} \mathrm{a}, 3^{\prime}}=5.8 \mathrm{~Hz}, 1 \mathrm{H}\right.$; H 2'a), $2.90\left(\mathrm{dd}, J_{\mathrm{gem}}=14.1, J_{\text {vic }}=8.8,1 \mathrm{H} ; \mathrm{bCH}_{2}\right), 3.22\left(\mathrm{dd}, J_{\mathrm{gem}}=14.1\right.$, $\left.J_{\text {vic }}=4.3 \mathrm{~Hz}, 1 \mathrm{H} ; \mathrm{aCH}_{2}\right), 3.46\left(\mathrm{dd}, J_{\text {vic }}=8.8,4.3 \mathrm{~Hz}, 1 \mathrm{H} ; \mathrm{CH}\right), 3.51(\mathrm{dd}$, $\left.J_{\text {gem }}=11.8, J_{5^{\prime} \mathrm{b}, 4^{\prime}}=4.3 \mathrm{~Hz}, 1 \mathrm{H} ; \mathrm{H} 5^{\prime} \mathrm{b}\right), 3.58\left(\mathrm{dd}, J_{\mathrm{gem}}=11.8, J_{5^{\prime} \mathrm{a}, 4^{\prime}}=4.6 \mathrm{~Hz}\right.$, $\left.1 \mathrm{H} ; \mathrm{H} 5^{\prime} \mathrm{a}\right), 3.84\left(\mathrm{td}, J_{4^{\prime}, 5^{\prime}}=4.6,4.3, J_{4^{\prime}, 3^{\prime}}=2.4 \mathrm{~Hz}, 1 \mathrm{H} ; \mathrm{H} 4^{\prime}\right), 4.37(\mathrm{dt}$, $\left.J_{3^{\prime}, 2^{\prime}}=5.8,2.7, J_{3^{\prime}, 4^{\prime}}=2.4 \mathrm{~Hz}, 1 \mathrm{H} ; \mathrm{H}^{\prime}\right), 5.12$ and $5.32(2 \times \mathrm{brs}, 2 \times 1 \mathrm{H} ; \mathrm{OH}$ $\left.3^{\prime}, 5^{\prime}\right), 6.20$ (brs, $\left.2 \mathrm{H} ; \mathrm{NH}_{2}\right), 6.58\left(\mathrm{dd}, J_{1^{\prime} 2^{\prime}}=8.3,6.0 \mathrm{~Hz}, 1 \mathrm{H} ; \mathrm{H} \mathrm{1}^{\prime}\right), 7.35$ (s, $4 \mathrm{H}$; $\mathrm{H} o, m$ phenylene), 7.47 (s, $1 \mathrm{H} ; \mathrm{H} 8), 8.13 \mathrm{ppm}(\mathrm{s}, 1 \mathrm{H} ; \mathrm{H} \mathrm{2})$; ${ }^{13} \mathrm{C}$ NMR (125.8 MHz, [D $]$ DMSO): $\delta=36.73\left(\mathrm{CH}_{2}\right), 39.92\left(\mathrm{CH}_{2} 2^{\prime}\right)$, $55.93(\mathrm{CH}), 62.19\left(\mathrm{CH}_{2} 5^{\prime}\right), 71.28\left(\mathrm{CH}^{\prime}\right), 83.18\left(\mathrm{CH} 1^{\prime}\right), 87.56\left(\mathrm{CH} 4^{\prime}\right)$, 100.55 (C 5), 116.56 (C 7), $120.30(\mathrm{CH} \mathrm{8),} 128.82$ and $130.10(\mathrm{CH} o, m$ phenylene), 132.79 (C $i$ phenylene), 136.28 (C p phenylene), 150.57 (C 4), 151.88 (CH 2), 157.44 (C 6), 169.48 ppm (CO); IR (KBr): $\tilde{v}=3391$, 2926, 1626, 1587, 1539, 1506, 1468, 1398, 1219, 1094, 1053, 951, 922 , $769 \mathrm{~cm}^{-1}$; MS (FAB): $m / z: 414(25)[M+1]^{+}, 255$ (100); HRMS (FAB): $m / z$ : calcd for $\mathrm{C}_{20} \mathrm{H}_{24} \mathrm{~N}_{5} \mathrm{O}_{5}$ : 414.1777; found: 414.1789 .

(S)-2-Amino-3-(4-\{[6-amino-9-(2-deoxy-[-D-erythro-pentofuranosyl)-7deazapurin-7-yl]ethynyl\}phenyl)propanoic acid (10): This compound was prepared by Method B from 2a, yield $94 \%$. $[\alpha]_{\mathrm{D}}^{20}=-23.3 \quad(c=2.40$, DMSO); ${ }^{1} \mathrm{H}$ NMR $\left(500 \mathrm{MHz},\left[\mathrm{D}_{6}\right] \mathrm{DMSO}\right): \delta=2.20 \quad\left(\mathrm{ddd}, J_{\mathrm{gem}}=13.1\right.$, $\left.J_{2^{\prime} \mathrm{b}, 1^{\prime}}=6.0, J_{2^{\prime} \mathrm{b}, 3^{\prime}}=2.9 \mathrm{~Hz}, 1 \mathrm{H} ; \mathrm{H} 2^{\prime} \mathrm{b}\right), 2.49\left(\mathrm{ddd}, J_{\mathrm{gem}}=13.1, J_{2^{\prime} \mathrm{a}, 1^{\prime}}=8.1\right.$, $\left.J_{2^{\prime} \mathrm{a}, 3^{\prime}}=5.7 \mathrm{~Hz}, 1 \mathrm{H} ; \mathrm{H} 2^{\prime} \mathrm{a}\right), 2.91\left(\mathrm{dd}, J_{\mathrm{gem}}=14.4, J_{\text {vic }}=8.0 \mathrm{~Hz}, 1 \mathrm{H} ; \mathrm{bCH}_{2}\right)$, $3.16\left(\mathrm{dd}, J_{\mathrm{gem}}=14.4, J_{\text {vic }}=4.7 \mathrm{~Hz}, 1 \mathrm{H} ; \mathrm{aCH}_{2}\right), 3.50\left(\mathrm{dd}, J_{\text {vic }}=8.0,4.7 \mathrm{~Hz}\right.$, $1 \mathrm{H} ; \mathrm{CH}), 3.52\left(\mathrm{dd}, J_{\mathrm{gem}}=11.7, J_{5^{\prime} \mathrm{b}, 4^{\prime}}=4.4 \mathrm{~Hz}, 1 \mathrm{H} ; \mathrm{H} 5^{\prime} \mathrm{b}\right), 3.60\left(\mathrm{dd}, J_{\mathrm{gem}}=\right.$ $11.7, J_{5^{\prime} \mathrm{a}, 4^{\prime}}=4.6 \mathrm{~Hz}, 1 \mathrm{H}$; H 5'a), $3.84\left(\mathrm{td}, J_{4^{\prime}, 5^{\prime}}=4.6,4.4, J_{4^{\prime}, 3^{\prime}}=2.6 \mathrm{~Hz}, 1 \mathrm{H}\right.$; $\left.\mathrm{H} 4^{\prime}\right), 4.36\left(\mathrm{dt}, J_{3^{\prime}, 2^{\prime}}=5.7,2.9, J_{3^{\prime}, 4^{\prime}}=2.6 \mathrm{~Hz}, 1 \mathrm{H} ; \mathrm{H} 3^{\prime}\right), 5.10$ and $5.32(2 \times$ brs, $2 \times 1 \mathrm{H}$; OH $\left.3^{\prime}, 5^{\prime}\right), 6.51\left(\mathrm{dd}, J_{1^{\prime} 2^{\prime}}=8.1,6.0 \mathrm{~Hz}, 1 \mathrm{H} ; \mathrm{H} 1^{\prime}\right), 6.70$ (brs, $2 \mathrm{H} ; \mathrm{NH}_{2}$ ), 7.32 (m, 2H; $\mathrm{H} m$ phenylene), 7.51 (m, 2H; $\mathrm{H} o$ phenylene), $7.86(\mathrm{~s}, 1 \mathrm{H} ; \mathrm{H}), 8.15 \mathrm{ppm}(\mathrm{s}, 1 \mathrm{H} ; \mathrm{H} 2) ;{ }^{13} \mathrm{C} \mathrm{NMR}(125.8 \mathrm{MHz}$, [D $\mathrm{D}_{6}$ DMSO): $\delta=36.95\left(\mathrm{CH}_{2}\right), 39.86\left(\mathrm{CH}_{2} 2^{\prime}\right), 55.32(\mathrm{CH}), 62.06\left(\mathrm{CH}_{2} 5^{\prime}\right)$, $71.14\left(\mathrm{CH} \mathrm{3}^{\prime}\right), 82.94(\mathbf{C}=\mathrm{C}$ phenylene $), 83.40\left(\mathrm{CH} 1^{\prime}\right), 87.76\left(\mathrm{CH} 4^{\prime}\right)$, 91.38 ( $\mathrm{C}=\mathbf{C}$ phenylene), 94.96 (C 7), 102.31 (C 5), 120.79 (C $i$ phenyl ene), 126.78 (CH 8), 129.98 ( $\mathrm{CH} m$ phenylene), 131.25 ( $\mathrm{CH} o$ phenyl ene), 138.29 (C p phenylene), 149.58 (C 4), 153.01 (CH 2), 157.80 (C 6), $169.42 \mathrm{ppm}$ (CO); IR (KBr): $\tilde{v}=3435,2211,1629,1593,1573,1505,1456$, 1400, 1236, 1088, 1057, 922, $794 \mathrm{~cm}^{-1}$; MS (FAB): $m / z: 438(20)[M+1]^{+}$, 419 (100), 375 (40), 322 (10) $[M-\mathrm{dRf}+2]^{+}$; HRMS (FAB): $m / z$ : calcd for $\mathrm{C}_{22} \mathrm{H}_{24} \mathrm{~N}_{5} \mathrm{O}_{5}$ : 438.1777; found: 438.1797

(S)-2-Amino-3-\{4-[1-(2-deoxy- $\beta$-D-erythro-pentofuranosyl)-2,4-dioxo1,2,3,4-tetrahydropyrimidin-5-yl]phenyl\}propanoic acid (8): This com pound was prepared by Method A from 3a, yield $78 \%$. $[\alpha]_{\mathrm{D}}^{20}=-17.8(c=$ 2.72, DMSO); ${ }^{1} \mathrm{H}$ NMR $\left(400 \mathrm{MHz},\left[\mathrm{D}_{6}\right] \mathrm{DMSO}\right): \delta=2.16\left(\mathrm{ddd}, J_{\mathrm{gem}}=\right.$ $\left.13.3, J_{2 \mathrm{~b}, 1^{\prime}}=6.2, J_{2^{\prime} \mathrm{b}, 3^{\prime}}=3.7 \mathrm{~Hz}, 1 \mathrm{H} ; \mathrm{H} 2^{\prime} \mathrm{b}\right), 2.22\left(\mathrm{ddd}, J_{\mathrm{gem}}=13.3, J_{2^{\prime} \mathrm{a}, 1^{\prime}}=\right.$ $\left.7.0, J_{2^{\prime} \mathrm{a}, 3^{\prime}}=5.9 \mathrm{~Hz}, 1 \mathrm{H} ; \mathrm{H} 2^{\prime} \mathrm{a}\right), 2.87\left(\mathrm{dd}, J_{\mathrm{gem}}=14.2, J_{\mathrm{vic}}=7.9,1 \mathrm{H} ; \mathrm{bCH}_{2}\right)$, $3.14\left(\mathrm{dd}, J_{\text {gem }}=14.2, J_{\text {vic }}=4.3 \mathrm{~Hz}, 1 \mathrm{H} ; \mathrm{aCH}_{2}\right), 3.45\left(\mathrm{dd}, J_{\text {vic }}=7.9,4.3 \mathrm{~Hz}\right.$, $1 \mathrm{H} ; \mathrm{CH}), 3.57\left(\mathrm{dd}, J_{\mathrm{gem}}=11.8, J_{5^{\prime} \mathrm{b}, 4^{\prime}}=3.3 \mathrm{~Hz}, 1 \mathrm{H} ; \mathrm{H} 5^{\prime} \mathrm{b}\right), 3.62\left(\mathrm{dd}, J_{\mathrm{gem}}=\right.$ $11.8, J_{5^{\prime} \mathrm{a}, 4^{\prime}}=3.1 \mathrm{~Hz}, 1 \mathrm{H}$; H 5'a), $3.82\left(\mathrm{q}, J_{4^{\prime}, 5^{\prime}}=3.3,3.1, J_{4^{\prime}, 3^{\prime}}=3.1 \mathrm{~Hz}, 1 \mathrm{H}\right.$; $\left.\mathrm{H} 4^{\prime}\right), 4.29\left(\mathrm{dt}, J_{3^{\prime}, 2^{\prime}}=5.9,3.7, J_{3^{\prime}, 4^{\prime}}=3.1 \mathrm{~Hz}, 1 \mathrm{H} ; \mathrm{H}^{\prime}\right), 5.105 .40(\mathrm{br}, 2 \mathrm{H}$; $\left.\mathrm{OH} 3^{\prime}, 5^{\prime}\right), 6.23\left(\mathrm{t}, J_{1^{\prime} 2^{\prime}}=7.0,6.2 \mathrm{~Hz}, 1 \mathrm{H} ; \mathrm{H} 1^{\prime}\right), 7.26$ (m, $2 \mathrm{H} ; \mathrm{H} m$ phenyl ene), 7.48 (m, 2H; H o phenylene), 8.16 (s, 1H; H 6), 11.49 ppm (brs, $1 \mathrm{H} ; \mathrm{NH}) ;{ }^{13} \mathrm{C} \mathrm{NMR}\left(100.6 \mathrm{MHz},\left[\mathrm{D}_{6}\right] \mathrm{DMSO}\right): \delta=36.78\left(\mathrm{CH}_{2}\right), 40.29$ $\left(\mathrm{CH}_{2} 2^{\prime}\right), 55.55(\mathrm{CH}), 61.19\left(\mathrm{CH}_{2} 5^{\prime}\right), 70.47\left(\mathrm{CH}^{\prime}\right), 84.67\left(\mathrm{CH} 1^{\prime}\right), 87.73$ ( $\left.\mathrm{CH} 4^{\prime}\right), 113.54$ (C 5), 127.93 ( $\mathrm{CH} o$ phenylene), 129.36 ( $\mathrm{CH} m$ phenyl ene), 131.54 (C $i$ phenylene), 136.70 (C p phenylene), 137.80 (CH 6), 150.11 (C 2), 162.30 (C 4), 169.62 ppm (CO); IR (KBr): $\tilde{v}=3586,3404$ $1695,1665,1649,1599,1471,1415,1350,1293,1099,1039,785 \mathrm{~cm}^{-1}$; MS $(\mathrm{FAB}): \mathrm{m} / \mathrm{z}: 414$ (100) $[M+\mathrm{Na}]^{+}$; HRMS (FAB): $\mathrm{m} / \mathrm{z}:$ calcd for $\mathrm{C}_{18} \mathrm{H}_{21} \mathrm{~N}_{3} \mathrm{O}_{7} \mathrm{Na}$ : 414.1277; found: 414.1267. 
(S)-2-Amino-3-(4-\{[1-(2-deoxy- $\beta$-D-erythro-pentofuranosyl)-2,4-dioxo1,2,3,4-tetrahydropyrimidin-5-yl]ethynyl\}phenyl)propanoic acid (11): This compound was prepared by Method B from 3a, yield $70 \% .[\alpha]_{\mathrm{D}}^{20}=-20.9$ $(c=2.06$, DMSO $) ;{ }^{1} \mathrm{H}$ NMR $\left(500 \mathrm{MHz},\left[\mathrm{D}_{6}\right] \mathrm{DMSO}\right): \delta=2.15\left(\mathrm{ddd}, J_{\mathrm{gem}}=\right.$ $\left.13.5, J_{2^{\prime} \mathrm{b}, 1^{\prime}}=6.3, J_{2^{\prime} \mathrm{b}, 3^{\prime}}=4.2 \mathrm{~Hz}, 1 \mathrm{H} ; \mathrm{H} 2^{\prime} \mathrm{b}\right), 2.17\left(\mathrm{ddd}, J_{\mathrm{gem}}=13.5, J_{2^{\prime} \mathrm{a}, 1^{\prime}}=\right.$ $\left.6.8, J_{2^{\prime} \mathrm{a}, 3^{\prime}}=5.8 \mathrm{~Hz}, 1 \mathrm{H} ; \mathrm{H} \mathrm{2}^{\prime} \mathrm{a}\right), 2.88\left(\mathrm{br}, 1 \mathrm{H} ; \mathrm{bCH}_{2}\right), 3.17$ (br, $\left.1 \mathrm{H} ; \mathrm{aCH}_{2}\right)$, $3.42(\mathrm{br}, 1 \mathrm{H} ; \mathrm{CH}), 3.59$ and $3.65\left(2 \times \mathrm{dd}, J_{\mathrm{gem}}=11.9, J_{5^{\prime}, 4^{\prime}}=3.4 \mathrm{~Hz}, 2 \mathrm{H} ; \mathrm{H}\right.$ $\left.5^{\prime}\right), 3.81\left(\mathrm{q}, J_{4^{\prime}, 5^{\prime}}=3.4, J_{4^{\prime}, 3^{\prime}}=3.2 \mathrm{~Hz}, 1 \mathrm{H} ; \mathrm{H} 4^{\prime}\right), 4.26\left(\mathrm{dt}, J_{3^{\prime}, 2^{\prime}}=5.8,4.2\right.$, $\left.J_{3^{\prime}, 4^{\prime}}=3.2,1 \mathrm{H} ; \mathrm{H}^{\prime}\right), 5.23$ and $5.33\left(2 \times \mathrm{brs}, 2 \times 1 \mathrm{H}\right.$; OH $\left.3^{\prime}, 5^{\prime}\right), 6.12(\mathrm{t}$, $J_{1^{\prime} 2^{\prime}}=6.8,6.3 \mathrm{~Hz}, 1 \mathrm{H} ; \mathrm{H} 1^{\prime}$ ), 7.30 (brm, 2H; $\mathrm{H} \mathrm{m}$ phenylene), 7.37 (bm, $2 \mathrm{H}$; H $o$ phenylene), $8.37 \mathrm{ppm}(\mathrm{s}, 1 \mathrm{H} ; \mathrm{H} 6) ;{ }^{13} \mathrm{C} \mathrm{NMR}(100.6 \mathrm{MHz}$, [D $]$ DMSO $): \delta=40.43\left(\mathrm{CH}_{2} 2^{\prime}\right), 55.21(\mathrm{CH}), 61.00\left(\mathrm{CH}_{2} 5^{\prime}\right), 70.11(\mathrm{CH}$ $\left.3^{\prime}\right), 82.31(\mathbf{C}=\mathrm{C}$ phenylene $), 85.06\left(\mathrm{CH} 1^{\prime}\right), 87.80\left(\mathrm{CH} 4^{\prime}\right), 92.14(\mathrm{C}=\mathbf{C}$ phenylene), 98.51 (C 5), 120.68 (C $i$ phenylene), 129.99 ( $\mathrm{CH} m$ phenyl ene), 131.36 ( $\mathrm{CH}$ o phenylene), 143.97 (CH 6), 149.66 (C 2), 161.69 (C 4), $167.66 \mathrm{ppm}(\mathrm{CO})\left(\mathrm{CH}_{2}\right.$ and $\mathrm{C} p$ phenylene not observed due to signal broadening); IR $(\mathrm{KBr}): \tilde{v}=3423,2815,1695,1642,1618,1533,1511$, 1464, 1412, 1314, 1274, 1199, 1154, 1098, 1052, $966 \mathrm{~cm}^{-1}$; MS (FAB): $m / z$ : $438(20)[M+\mathrm{Na}]^{+}, 416(80)$; HRMS (FAB): $m / z$ : calcd for $\mathrm{C}_{20} \mathrm{H}_{22} \mathrm{~N}_{3} \mathrm{O}_{7}$ : 416.1458; found: 416.1438; elemental analysis (\%) calcd for $\mathrm{C}_{20} \mathrm{H}_{21} \mathrm{~N}_{3} \mathrm{O}_{7} \cdot 2 \mathrm{H}_{2} \mathrm{O}$ (451.4): C 53.21, H 5.58, N 9.31; found: $\mathrm{C} 52.91, \mathrm{H}$ 5.31, N 8.99 .

\section{(S)-2-Amino-3-(4-\{[6-amino-9-(2-deoxy- $\beta$-D-erythro-pentofuranosyl)-} purin-8-yl]ethynyl\}phenyl)propanoic acid 5'-O-triphosphate (A2): This compound was prepared by Method D from 1b, yield $61 \% .{ }^{1} \mathrm{H}$ NMR $\left(500 \mathrm{MHz}, \quad \mathrm{D}_{2} \mathrm{O}+\mathrm{Et}_{3} \mathrm{~N}, \quad \operatorname{ref}_{\text {dioxane }}=3.75 \mathrm{ppm}\right): \delta=1.12 \quad\left(\mathrm{t}, \quad J_{\text {vic }}=7.2 \mathrm{~Hz}\right.$, $27 \mathrm{H} ; \mathrm{CH}_{3} \mathrm{CH}_{2} \mathrm{~N}$ ), 2.56 (brm, $\left.1 \mathrm{H} ; \mathrm{H}_{2}^{\prime} \mathrm{b}\right), 2.83$ (q, $J_{\text {vic }}=7.2 \mathrm{~Hz}, 18 \mathrm{H}$; $\left.\mathrm{CH}_{3} \mathrm{CH}_{2} \mathrm{~N}\right), 2.87\left(\mathrm{dd}, J_{\text {gem }}=13.5, J_{\text {vic }}=7.2 \mathrm{~Hz}, 1 \mathrm{H} ; \mathrm{bCH}_{2}\right), 3.03\left(\mathrm{dd}, J_{\mathrm{gem}}=\right.$ $\left.13.5, J_{\text {vic }}=4.9 \mathrm{~Hz}, 1 \mathrm{H} ; \mathrm{aCH}_{2}\right), 3.453 .55\left(\mathrm{~m}, 2 \mathrm{H} ; \mathrm{H}^{\prime} \mathrm{a}\right.$ and $\left.\mathrm{CH}\right), 4.13$ (brm, 1H; H 5'b), $4.284 .32\left(\mathrm{~m}, 2 \mathrm{H} ; \mathrm{H}^{\prime}\right.$ and $\left.\mathrm{H} 5^{\prime} \mathrm{a}\right), 4.85\left(\mathrm{q}, J_{3^{\prime} 2^{\prime}}=\right.$ $\left.J_{3^{\prime}, 4^{\prime}}=4.1 \mathrm{~Hz}, 1 \mathrm{H} ; \mathrm{H} 3^{\prime}\right), 6.67\left(\mathrm{t}, J_{1^{\prime} 2^{\prime}}=7.2 \mathrm{~Hz}, 1 \mathrm{H} ; \mathrm{H} 1^{\prime}\right), 7.27(\mathrm{~m}, 2 \mathrm{H} ; \mathrm{H}$ $m$ phenylene), 7.57 (m, 2H; H $o$ phenylene), $8.22 \mathrm{ppm}(\mathrm{s}, 1 \mathrm{H} ; \mathrm{H} 2)$; ${ }^{13} \mathrm{C} \mathrm{NMR} \quad\left(125.8 \mathrm{MHz}, \quad \mathrm{D}_{2} \mathrm{O}+\mathrm{Et}_{3} \mathrm{~N}, \quad \operatorname{ref}_{\text {dioxane }}=69.3 \mathrm{ppm}\right): \quad \delta=11.85$ $\left(\mathbf{C H}_{3} \mathrm{CH}_{2} \mathrm{~N}\right), 38.73\left(\mathrm{CH}_{2} 2^{\prime}\right), 43.55\left(\mathrm{CH}_{2}\right), 48.69\left(\mathrm{CH}_{3} \mathbf{C H}_{2} \mathrm{~N}\right), 59.85(\mathrm{CH})$, $68.34\left(\mathrm{CH}_{2} 5^{\prime}\right), 73.73\left(\mathrm{CH} \mathrm{3}^{\prime}\right), 79.61(\mathrm{C}=\mathbf{C}$ pur$), 87.42\left(\mathrm{CH} 1^{\prime}\right), 88.29(\mathrm{~d}$, $\left.J_{\mathrm{CP}}=9 \mathrm{~Hz} ; \mathrm{CH} 4^{\prime}\right), 99.95(\mathbf{C}=\mathrm{C}$ pur$), 120.19$ (C $i$ phenylene $), 121.25(\mathrm{C}$ 5), 132.50 ( $\mathrm{CH} m$ phenylene), 134.86 ( $\mathrm{CH} o$ phenylene), 137.94 (C 8), 144.12 (C p phenylene), 151.32 (C 4), 156.32 ( $\mathrm{CH} 2), 157.78$ (C 6), $184.34 \mathrm{ppm}(\mathrm{CO}) ;{ }^{31} \mathrm{P}\left({ }^{1} \mathrm{H}\right.$ dec.) NMR $\left(162 \mathrm{MHz}, \mathrm{D}_{2} \mathrm{O}+\mathrm{Et}_{3} \mathrm{~N}, \mathrm{ref}_{\mathrm{H}_{3} \mathrm{PO}_{4}}=\right.$ 0 ppm): $\delta=-22.49$ (brt, $J=20.8,19.5 \mathrm{~Hz} ; \mathrm{P}_{\beta}$ ), -11.19 (d, $J=19.5 \mathrm{~Hz}$; $\left.\mathrm{P}_{\alpha}\right),-6.40 \mathrm{ppm}\left(\mathrm{d}, J=20.8 \mathrm{~Hz} ; \mathrm{P}_{\gamma}\right) ; \mathrm{MS}\left(\mathrm{ES}^{-}\right): m / z: 677$ (100) $[M-1]$, 579 (25); HRMS (ES ${ }^{-}$): $m / z$ : calcd for $\mathrm{C}_{21} \mathrm{H}_{24} \mathrm{~N}_{6} \mathrm{O}_{14} \mathrm{P}_{3}$ : 677.0563; found: 677.0552 .

(S)-2-Amino-3-\{4-[6-amino-9-(2-deoxy-\}-D-erythro-pentofuranosyl)-7deazapurin-7-yl]phenyl\}propanoic acid $5^{\prime}$ - $\boldsymbol{O}$-triphosphate (A3): This com pound was prepared by Method $\mathrm{C}$ from $\mathbf{2 b}$, yield $66 \%$. ${ }^{1} \mathrm{H} \mathrm{NMR}$ $\left(400 \mathrm{MHz}, \quad \mathrm{D}_{2} \mathrm{O}, \quad \operatorname{ref}_{\text {dioxane }}=3.75 \mathrm{ppm}\right): \delta=1.26 \quad\left(\mathrm{t}, J_{\text {vic }}=7.4 \mathrm{~Hz}, 27 \mathrm{H}\right.$; $\left.\mathrm{CH}_{3} \mathrm{CH}_{2} \mathrm{~N}\right), 2.45\left(\mathrm{ddd}, J_{\mathrm{gem}}=14.2, J_{2^{\prime} \mathrm{b}, 1^{\prime}}=6.4, J_{2^{\prime} \mathrm{b}, 3^{\prime}}=3.3 \mathrm{~Hz}, 1 \mathrm{H} ; \mathrm{H} 2^{\prime} \mathrm{b}\right.$ ), $2.68\left(\mathrm{ddd}, J_{\text {gem }}=14.2, J_{2^{\prime} \mathrm{a}, 1^{\prime}}=7.9, J_{2^{\prime} \mathrm{a}, 3^{\prime}}=6.2 \mathrm{~Hz}, 1 \mathrm{H} ; \mathrm{H} 2^{\prime} \mathrm{a}\right), 3.16(\mathrm{dd}$, $\left.J_{\text {gem }}=14.3, \quad J_{\text {vic }}=8.5 \mathrm{~Hz}, \quad 1 \mathrm{H} ; \quad \mathrm{bCH}_{2}\right), \quad 3.17 \quad\left(\mathrm{q}, \quad J_{\text {vic }}=7.4 \mathrm{~Hz}, \quad 18 \mathrm{H}\right.$; $\left.\mathrm{CH}_{3} \mathrm{CH}_{2} \mathrm{~N}\right), 3.36\left(\mathrm{dd}, J_{\mathrm{gem}}=14.3, J_{\text {vic }}=4.7 \mathrm{~Hz}, 1 \mathrm{H} ; \mathrm{aCH}_{2}\right), 4.02\left(\mathrm{dd}, J_{\text {vic }}=\right.$ 8.5, $4.7 \mathrm{~Hz}, 1 \mathrm{H} ; \mathrm{CH}), 4.104 .25\left(\mathrm{~m}, 3 \mathrm{H} ; \mathrm{H}^{\prime}\right.$ and $\left.\mathrm{H}^{\prime}\right), 4.74(\mathrm{brm}, 1 \mathrm{H}$; H 3'), 6.64 (t, $\left.J_{1^{\prime} 2^{\prime}}=7.9,6.4 \mathrm{~Hz}, 1 \mathrm{H} ; \mathrm{H} 1^{\prime}\right), 7.39$ (m, $2 \mathrm{H} ; \mathrm{H} m$ phenylene), 7.44 (m, 2H; H o phenylene), 7.58 (s, $1 \mathrm{H} ; \mathrm{H} 8), 8.17 \mathrm{ppm}(\mathrm{s}, 1 \mathrm{H} ; \mathrm{H} 2)$; ${ }^{13} \mathrm{C} \mathrm{NMR}\left(100.6 \mathrm{MHz}, \mathrm{D}_{2} \mathrm{O}\right.$, $\left.\operatorname{ref}_{\text {dioxane }}=69.3 \mathrm{ppm}\right): \delta=10.94\left(\mathrm{CH}_{3} \mathrm{CH}_{2} \mathrm{~N}\right)$, $38.86\left(\mathrm{CH}_{2}\right), 41.53\left(\mathrm{CH}_{2} 2^{\prime}\right), 49.37\left(\mathrm{CH}_{3} \mathrm{CH}_{2} \mathrm{~N}\right), 58.71(\mathrm{CH}), 68.35(\mathrm{~d}$, $\left.J_{\mathrm{C}, \mathrm{P}}=5 \mathrm{~Hz} ; \mathrm{CH}_{2} 5^{\prime}\right), 74.06\left(\mathrm{CH} \mathrm{3}^{\prime}\right), 85.82\left(\mathrm{CH} 1^{\prime}\right), 87.98\left(\mathrm{~d}, J_{\mathrm{C}, \mathrm{P}}=9 \mathrm{~Hz}\right.$; CH 4'), 103.11 (C 5), 121.07 (C 7), 123.76 (CH 8), 131.96 (CH $o$ phenyl ene), 132.83 ( $\mathrm{CH} m$ phenylene), 134.98 (C $i$ phenylene), 137.28 (C $p$ phenylene), 151.63 (CH 2), 151.85 (C 4), 158.06 (C 6), 176.67 ppm (CO); ${ }^{31} \mathrm{P}\left({ }^{1} \mathrm{H}\right.$ dec.) NMR $\left(162 \mathrm{MHz}, \mathrm{D}_{2} \mathrm{O}, \mathrm{ref}_{\mathrm{H}_{3} \mathrm{PO}_{4}}=0 \mathrm{ppm}\right): \delta=-23.17(\mathrm{t}, J=$ $\left.19.7,19.0 \mathrm{~Hz} ; \mathrm{P}_{\beta}\right),-11.40\left(\mathrm{~d}, J=19.7 \mathrm{~Hz} ; \mathrm{P}_{\alpha}\right),-10.47 \mathrm{ppm}(\mathrm{d}, J=$ $\left.19.0 \mathrm{~Hz} ; \mathrm{P}_{\gamma}\right)$; $\mathrm{MS}\left(\mathrm{ES}^{-}\right): \mathrm{m} / z$ : 652 (100) $[M-1]^{-}, 572$ (20), 554 (20); HRMS (ES ${ }^{-}$): $m / z$ : calcd for $\mathrm{C}_{20} \mathrm{H}_{25} \mathrm{N5}_{6} \mathrm{O}_{14} \mathrm{P}_{3}$ : 652.0611; found: 652.0579 . (S)-2-Amino-3-(4-\{[6-amino-9-(2-deoxy- $\beta$-D-erythro-pentofuranosyl)-7deazapurin-7-yl]ethynyl\}phenyl)propanoic acid $\mathbf{5}^{\prime}$-O-triphosphate (A4): This compound was prepared by Method D from $2 \mathbf{b}$, yield $67 \%$. ${ }^{1} \mathrm{H}$ NMR $\left(400 \mathrm{MHz}, \mathrm{D}_{2} \mathrm{O}, \mathrm{ref}_{\text {dioxane }}=3.75 \mathrm{ppm}\right): \delta=1.25\left(\mathrm{t}, J_{\mathrm{vic}}=7.4 \mathrm{~Hz}\right.$,
$27 \mathrm{H} ; \mathrm{CH}_{3} \mathrm{CH}_{2} \mathrm{~N}$ ), 2.46 (brddd, $J_{\mathrm{gem}}=14.2, J_{2^{\prime} \mathrm{b}, 1^{\prime}}=6.0, J_{2^{\prime} \mathrm{b}, 3^{\prime}}=3.0 \mathrm{~Hz}, 1 \mathrm{H}$; H 2'b), 2.64 (brdt, $\left.J_{\text {gem }}=14.2, J_{2^{\prime} \mathrm{a}, 1^{\prime}}=J_{2^{\prime} \mathrm{a}, 3^{\prime}}=6.5 \mathrm{~Hz}, 1 \mathrm{H} ; \mathrm{H} 2^{\prime} \mathrm{a}\right), 3.07$ (dd, $\left.J_{\text {gem }}=14.6, \quad J_{\text {vic }}=8.5 \mathrm{~Hz}, \quad 1 \mathrm{H} ; \quad \mathrm{bCH}_{2}\right), \quad 3.16 \quad\left(\mathrm{q}, \quad J_{\text {vic }}=7.4 \mathrm{~Hz}, \quad 18 \mathrm{H}\right.$; $\left.\mathrm{CH}_{3} \mathrm{CH}_{2} \mathrm{~N}\right), 3.30\left(\mathrm{dd}, J_{\text {gem }}=14.6, J_{\text {vic }}=4.9 \mathrm{~Hz}, 1 \mathrm{H} ; \mathrm{aCH}_{2}\right), 3.98\left(\mathrm{dd}, J_{\text {vic }}=\right.$ 8.5, $4.9 \mathrm{~Hz}, 1 \mathrm{H} ; \mathrm{CH}), 4.114 .26\left(\mathrm{~m}, 3 \mathrm{H} ; \mathrm{H}^{\prime}\right.$ and $\left.\mathrm{H} 5^{\prime}\right), 4.73$ (brm, $1 \mathrm{H}$; H 3 $\left.3^{\prime}\right), 6.42\left(\mathrm{t}, J_{1^{\prime} 2^{\prime}}=6.5,6.0 \mathrm{~Hz}, 1 \mathrm{H} ; \mathrm{H} 1^{\prime}\right), 7.22(\mathrm{~m}, 2 \mathrm{H} ; \mathrm{H} m$ phenylene), 7.38 (m, 2H; H o phenylene), 7.77 (s, 1H; H 8), 8.13 ppm (s, $1 \mathrm{H} ; \mathrm{H} 2)$; ${ }^{13} \mathrm{C} \mathrm{NMR} \quad\left(100.6 \mathrm{MHz}, \quad \mathrm{D}_{2} \mathrm{O}+\mathrm{Et}_{3} \mathrm{~N}, \quad \operatorname{ref}_{\text {dioxane }}=69.3 \mathrm{ppm}\right): \quad \delta=11.42$ $\left(\mathrm{CH}_{3} \mathrm{CH}_{2} \mathrm{~N}\right), 41.14\left(\mathrm{CH}_{2}\right), 44.89\left(\mathrm{CH}_{2} 2^{\prime}\right), 48.98\left(\mathrm{CH}_{3} \mathbf{C H}_{2} \mathrm{~N}\right), 59.98(\mathrm{CH})$, $68.18\left(\mathrm{~d}, J_{\mathrm{C}, \mathrm{P}}=6 \mathrm{~Hz} ; \mathrm{CH}_{2} 5^{\prime}\right), 73.56\left(\mathrm{CH}^{\prime}\right), 84.29(\mathbf{C}=\mathrm{C}$ phenylene $)$, $85.56\left(\mathrm{CH} \mathrm{1}^{\prime}\right), 88.12\left(\mathrm{~d}, J_{\mathrm{C}, \mathrm{P}}=9 \mathrm{~Hz} ; \mathrm{CH} 4^{\prime}\right), 95.01$ (C=C phenylene), 99.49 (C 7), 105.63 (C 5), 122.93 (C $i$ phenylene), 128.80 (CH 8), 132.34 (CH $m$ phenylene), 133.98 ( $\mathrm{CH} o$ phenylene), 141.82 (C $p$ phenylene), 151.56 (C 4), 155.18 (CH 2), 160.36 (C 6), 184.29 ppm (CO); ${ }^{31} \mathrm{P}\left({ }^{1} \mathrm{H}\right.$ dec.) NMR $\left(162 \mathrm{MHz}, \mathrm{D}_{2} \mathrm{O}, \mathrm{ref}_{\mathrm{H}_{3} \mathrm{PO}_{4}}=0 \mathrm{ppm}\right): \delta=-23.05\left(\mathrm{t}, J=20.0,19.3 \mathrm{~Hz} ; \mathrm{P}_{\beta}\right)$, $-11.28\left(\mathrm{~d}, J=20.0 \mathrm{~Hz} ; \mathrm{P}_{\alpha}\right),-10.35\left(\mathrm{~d}, J=19.3 \mathrm{~Hz} ; \mathrm{P}_{\gamma}\right) ; \mathrm{MS}\left(\mathrm{ES}^{-}\right): \mathrm{m} / z$ : 676 (100) $[M-1]^{-} ;$HRMS $\left(\mathrm{ES}^{-}\right): \mathrm{m} / z$ : calcd for $\mathrm{C}_{22} \mathrm{H}_{254} \mathrm{~N}_{6} \mathrm{O}_{14} \mathrm{P}_{3}$ : 676.0611; found: 676.0629 .

(S)-2-Amino-3-\{4-[1-(2-deoxy- $\beta$-D-erythro-pentofuranosyl)-2,4-dioxo1,2,3,4-tetrahydropyrimidin-5-yl]phenyl\}propanoic acid 5 - $O$-triphosphate (T1): This compound was prepared by Method C from 3b, yield $56 \%$ ${ }^{1} \mathrm{H}$ NMR $\left(500 \mathrm{MHz}, \mathrm{D}_{2} \mathrm{O}, \mathrm{ref}_{\text {dioxane }}=3.75 \mathrm{ppm}\right): \delta=1.27\left(\mathrm{t}, J_{\text {vic }}=7.3 \mathrm{~Hz}\right.$, $\left.27 \mathrm{H} ; \mathrm{CH}_{3} \mathrm{CH}_{2} \mathrm{~N}\right), 2.392 .48\left(\mathrm{~m}, 2 \mathrm{H} ; \mathrm{H} 2^{\prime}\right), 3.05\left(\mathrm{dd}, J_{\mathrm{gem}}=14.6, J_{\mathrm{vic}}=\right.$ $\left.9.5 \mathrm{~Hz}, 1 \mathrm{H} ; \mathrm{bCH}_{2}\right), 3.21\left(\mathrm{q}, J_{\text {vic }}=7.3 \mathrm{~Hz}, 18 \mathrm{H} ; \mathrm{CH}_{3} \mathrm{CH}_{2} \mathrm{~N}\right), 3.41$ (dd, $\left.J_{\text {gem }}=14.6, J_{\text {vic }}=4.3 \mathrm{~Hz}, 1 \mathrm{H} ; \mathrm{aCH}_{2}\right), 3.98\left(\mathrm{dd}, J_{\text {vic }}=9.5,4.3 \mathrm{~Hz}, 1 \mathrm{H} ; \mathrm{CH}\right)$, $4.134 .24\left(\mathrm{~m}, 3 \mathrm{H} ; \mathrm{H} 4^{\prime}\right.$ and $\left.\mathrm{H} 5^{\prime}\right), 4.65\left(\mathrm{td}, J_{3^{\prime} 2^{\prime}}=4.4, J_{3^{\prime} 4^{\prime}}=2.7 \mathrm{~Hz}, 1 \mathrm{H}\right.$; H 3'), 6.38 (t, $\left.J_{1^{\prime} 2^{\prime}}=7.0 \mathrm{~Hz}, 1 \mathrm{H} ; \mathrm{H} 1^{\prime}\right), 7.40$ (m, 2H; H $m$ phenylene), 7.51 (m, 2H; H $o$ phenylene), 7.99 ppm (s, 1H; H 6); ${ }^{13} \mathrm{C} \mathrm{NMR} \mathrm{(125.8} \mathrm{MHz,}$ $\left.\mathrm{D}_{2} \mathrm{O}, \quad \operatorname{ref}_{\text {dioxane }}=69.3 \mathrm{ppm}\right): \delta=10.96\left(\mathrm{CH}_{3} \mathrm{CH}_{2} \mathrm{~N}\right), 39.00\left(\mathrm{CH}_{2}\right), 41.71$ $\left(\mathrm{CH}_{2} 2^{\prime}\right), 49.39\left(\mathrm{CH}_{3} \mathbf{C H}_{2} \mathrm{~N}\right), 58.85(\mathrm{CH}), 68.10\left(\mathrm{~d}, J_{\mathrm{C}, \mathrm{P}}=5 \mathrm{~Hz} ; \mathrm{CH}_{2} 5^{\prime}\right)$, 73.41 ( $\left.\mathrm{CH} \mathrm{3}^{\prime}\right), 88.22\left(\mathrm{CH} 1^{\prime}\right), 88.48$ (d, $\left.J_{\mathrm{C}, \mathrm{P}}=9, \mathrm{CH} 4^{\prime}\right), 118.41$ (C 5), 132.17 ( $\mathrm{CH} o$ phenylene), 132.33 ( $\mathrm{CH} m$ phenylene), 133.99 (C $i$ phenyl ene), 138.07 (C p phenylene), 141.66 (CH 6), 154.05 (C 2), 167.54 (C 4), $176.88 \mathrm{ppm}(\mathrm{CO}) ;{ }^{31} \mathrm{P}\left({ }^{1} \mathrm{H}\right.$ dec.) NMR (162 MHz, $\left.\mathrm{D}_{2} \mathrm{O}, \operatorname{ref}_{\mathrm{H}_{3} \mathrm{PO}_{4}}=0 \mathrm{ppm}\right)$ : $\delta=-23.33 \quad\left(\mathrm{t}, \quad J=20.1, \quad 19.9 \mathrm{~Hz} ; \mathrm{P}_{\beta}\right), \quad-11.87 \quad\left(\mathrm{~d}, \quad J=19.9 \mathrm{~Hz} ; \mathrm{P}_{\alpha}\right)$,

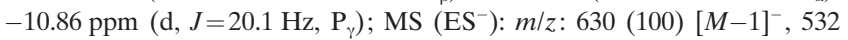
(30); HRMS (ES ${ }^{-}$): calcd for $\mathrm{C}_{18} \mathrm{H}_{23} \mathrm{~N}_{3} \mathrm{O}_{16} \mathrm{P}_{3}$ : 630.0291; found: 630.0294 . (S)-2-Amino-3-(4-\{[1-(2-deoxy- $\beta$-D-erythro-pentofuranosyl)-2,4-dioxo1,2,3,4-tetrahydropyrimidin-5-yl]ethynyl\}phenyl)propanoic acid $\mathbf{5}^{\prime}$-O $\boldsymbol{O}$-triphosphate (T2): This compound was prepared by Method D from $\mathbf{3 b}$, yield $66 \% .{ }^{1} \mathrm{H} \mathrm{NMR}\left(500 \mathrm{MHz}, \mathrm{D}_{2} \mathrm{O}+\mathrm{Et}_{3} \mathrm{~N}, \operatorname{ref}_{\text {dioxane }}=3.75 \mathrm{ppm}\right): \delta=1.22$ $\left(\mathrm{t}, J_{\mathrm{vic}}=7.3 \mathrm{~Hz}, 27 \mathrm{H} ; \mathrm{CH}_{3} \mathrm{CH}_{2} \mathrm{~N}\right), 2.36\left(\mathrm{ddd}, J_{\mathrm{gem}}=14.0, J_{2^{\prime} \mathrm{b}, 1^{\prime}}=7.3, J_{2^{\prime} \mathrm{b}, 3^{\prime}}=\right.$ $\left.6.6 \mathrm{~Hz}, 1 \mathrm{H} ; \mathrm{H} 2^{\prime} \mathrm{b}\right), 2.38\left(\mathrm{ddd}, J_{\mathrm{gem}}=14.0, J_{2^{\prime} \mathrm{a}, 1^{\prime}}=6.5, J_{2^{\prime} \mathrm{a}, 3^{\prime}}=4.3 \mathrm{~Hz}, 1 \mathrm{H}\right.$; H 2'a), 2.34 (dd, $\left.J_{\text {gem }}=13.9, J_{\text {vic }}=8.3 \mathrm{~Hz}, 1 \mathrm{H} ; \mathrm{bCH}_{2}\right), 3.08\left(\mathrm{dd}, J_{\text {gem }}=13.9\right.$, $\left.J_{\text {vic }}=5.4 \mathrm{~Hz}, 1 \mathrm{H} ; \mathrm{aCH}_{2}\right), 3.08\left(\mathrm{q}, J_{\text {vic }}=7.3 \mathrm{~Hz}, 18 \mathrm{H} ; \mathrm{CH}_{3} \mathrm{CH}_{2} \mathrm{~N}\right), 3.57(\mathrm{dd}$, $\left.J_{\text {vic }}=8.3,5.4 \mathrm{~Hz}, 1 \mathrm{H} ; \mathrm{CH}\right), 4.164 .27\left(\mathrm{~m}, 3 \mathrm{H} ; \mathrm{H}^{\prime}\right.$ and $\left.\mathrm{H}^{\prime}\right), 4.46(\mathrm{dt}$, $\left.J_{3^{\prime}, 2^{\prime}}=6.6,4.3, J_{3^{\prime}, 4^{\prime}}=3.6 \mathrm{~Hz}, 1 \mathrm{H} ; \mathrm{H}^{\prime}\right), 6.35\left(\mathrm{t}, J_{1^{\prime} 2^{\prime}}=7.3,6.5 \mathrm{~Hz}, 1 \mathrm{H} ; \mathrm{H}\right.$ $\left.1^{\prime}\right), 7.29(\mathrm{~m}, 2 \mathrm{H} ; \mathrm{H} m$ phenylene $), 7.56$ (m, 2H; $\mathrm{H} o$ phenylene $)$, $8.06 \mathrm{ppm}(\mathrm{s}, 1 \mathrm{H} ; \mathrm{H} 6) ;{ }^{13} \mathrm{C} \mathrm{NMR}\left(125.8 \mathrm{MHz}, \mathrm{D}_{2} \mathrm{O}+\mathrm{Et}_{3} \mathrm{~N}, \operatorname{ref}_{\text {dioxane }}=\right.$ $69.3 \mathrm{ppm}): \delta=11.19\left(\mathrm{CH}_{3} \mathrm{CH}_{2} \mathrm{~N}\right), 41.28\left(\mathrm{CH}_{2} 2^{\prime}\right), 42.82\left(\mathrm{CH}_{2}\right), 49.16$ $\left(\mathrm{CH}_{3} \mathrm{CH}_{2} \mathrm{~N}\right), 59.85(\mathrm{CH}), 68.02\left(\mathrm{~d}, J_{\mathrm{C}, \mathrm{P}}=5 \mathrm{~Hz} ; \mathrm{CH}_{2} 5^{\prime}\right), 73.03\left(\mathrm{CH} 3^{\prime}\right)$, $85.58(\mathrm{C}=\mathbf{C}$ pyr $), 87.87\left(\mathrm{~d}, J_{\mathrm{C}, \mathrm{P}}=9 \mathrm{~Hz} ; \mathrm{CH} 4^{\prime}\right), 87.99\left(\mathrm{CH} 1^{\prime}\right), 95.46(\mathbf{C}=\mathrm{C}$ pyr), 102.71 (C 5), 123.62 (C $i$ phenylene), 132.28 (CH $m$ phenylene), 134.29 (CH $o$ phenylene), 141.20 (C p phenylene), 145.82 (CH 6), 160.76 (C 2), 176.71 (C 4), $183.52 \mathrm{ppm}$ (CO); ${ }^{31} \mathrm{P}$ ( ${ }^{1} \mathrm{H}$ dec.) NMR (162 MHz, $\left.\mathrm{D}_{2} \mathrm{O}+\mathrm{Et}_{3} \mathrm{~N}, \mathrm{ref}_{\mathrm{H}_{3} \mathrm{PO}_{4}}=0 \mathrm{ppm}\right): \delta=-22.57\left(\mathrm{t}, J=21.0,19.8 \mathrm{~Hz} ; \mathrm{P}_{\beta}\right),-11.20$ $\left(\mathrm{d}, J=19.8 \mathrm{~Hz} ; \mathrm{P}_{\alpha}\right),-6.41 \mathrm{ppm}\left(\mathrm{d}, J=21.0 \mathrm{~Hz} ; \mathrm{P}_{\gamma}\right) ; \mathrm{MS}\left(\mathrm{ES}^{-}\right): m / z: 654$ (100) $[M-1], 448$ (70); HRMS $\left(\mathrm{ES}^{-}\right): \mathrm{m} / z$ : calcd for $\mathrm{C}_{24} \mathrm{H}_{20} \mathrm{~N}_{2} \mathrm{O}_{16} \mathrm{P}_{2}$ : 654.0288; found: 654.0287 .

Primer extension experiments: The reaction mixture $(20 \mu \mathrm{L})$ contained Pwo DNA polymerase (PeqLab, 1 unit), DMSO (2\%), dNTPs (either natural or functionalized, $200 \mu \mathrm{M})$, primer $(150 \mathrm{~nm}$, LT25TH: 5' CAA GGA CAA AAT ACC TGT ATT CCT T 3'), and template (225 nm, FVL35 A: 5' GAT CCC TGA CAG GGC AAG GAA TAC AGG TAT TTT GT $3^{\prime}$ ) in $P$ wo reaction buffer supplied by the manufacturer. LT25TH was labeled by use of $\left[\gamma^{32} \mathrm{P}\right]$ ATP according to standard tech niques. Reaction mixtures were incubated for $30 \mathrm{~min}$ at $55^{\circ} \mathrm{C}$ in a ther mal cycler and were stopped by addition of stop solution $(40 \mu \mathrm{L}, 80 \%$ 
[v/v] formamide, $20 \mathrm{~mm}$ EDTA, $0.025 \%$ [w/v] bromophenol blue, $0.025 \%$ $[\mathrm{w} / \mathrm{v}]$ xylene cyanol). Reaction mixtures were separated by use of a $12 \%$ denaturing PAGE. Visualization was performed by phosphoimaging.

Polymerase chain reactions: The PCR reaction mixture $(20 \mu \mathrm{L})$ con tained Pwo DNA polymerase (PeqLab, 2 units), DMSO (2\%), dNTPs (either natural or functionalized, $200 \mu \mathrm{M}$ ), primers LT25TH and L20 (5' GACATCATGAGAGACATCGC 3'), and a 98 mer template (5' GAC ATC ATG AGA GAC ATC GCC TCT GGG CTA ATA GGA CTA CTT CTA ATC TGT AAG AGC AGA TCC CTG GAC AGG CAA GGA ATA CAG GTA TTT TGT CCT TG $3^{\prime}$ ) in Pwo reaction buffer supplied by the manufacturer. $30 \mathrm{PCR}$ cycles were run under the follow ing conditions: denaturation for $1 \mathrm{~min}$ at $98^{\circ} \mathrm{C}$, annealing for $1 \mathrm{~min}$ at $55^{\circ} \mathrm{C}$, extension for $1.5 \mathrm{~min}$ at $72^{\circ} \mathrm{C}$, followed by a final extension step of $5 \mathrm{~min}$ at $72{ }^{\circ} \mathrm{C}$. PCR products were analyzed on a $2.5 \%$ agarose gel in $0.5 \times$ TBE buffer, followed by staining with ethidium bromide.

CD spectroscopy and thermal denaturation studies: CD spectra and melt ing temperatures were determined for a functionalized DNA duplex in which all natural dT had been replaced with the modified T2. A DNA duplex containing all natural nucleotides served as control. For prepara tive purposes a total volume of $500 \mu \mathrm{L}$ PCR was run as mentioned above and purification was carried out with a MinElute PCR Purification Kit (Qiagen). Samples were eluted with Tris $\mathrm{HCl}(10 \mathrm{~mm}, \mathrm{pH} 8.5)$ in $160 \mu \mathrm{L}$. Absorbance at $260 \mathrm{~nm}$ was determined with the aid of an ND $1000 \mathrm{spec}$ trophotometer (NanoDrop) and was as follows: $\mathrm{Abs}_{260}$ (control) $=0.948$; $\mathrm{Abs}_{260}($ sample T2 $)=0.533$. $10 \times$ PBS $(0.1 \mathrm{M}$ phosphate buffer with $27 \mathrm{~mm}$ $\mathrm{KCl}$ and $1.37 \mathrm{M} \mathrm{NaCl}, \mathrm{pH} 7.4$ ) was added to a final concentration of $1 \times$. $\mathrm{CD}$ spectra were recorded with a Jasco 720 instrument. The duplex DNA samples were heated to $94^{\circ} \mathrm{C}$ for $5 \mathrm{~min}$ and allowed to cool slowly to room temperature prior to measurements. A spectrum of the buffer was measured separately and subtracted from the spectra resulting from the samples. An average of 10 spectra was recorded in each experiment.

Melting curves were recorded on a Cary 100 bio UV/Vis instrument with temperature controller. Data were obtained from three individual cool ing/heating cycles. Melting temperatures $\left(T_{\mathrm{m}}\right.$ values in $\left.{ }^{\circ} \mathrm{C}\right)$ were obtained by plotting temperature versus absorbance and by applying a sigmoidal curve fit. The samples were the same as for CD spectra.

\section{Acknowledgements}

This work is a part of the research project Z40550506. It was supported by the "Center of Biomolecules and Complex Molecular Systems" (LC512), by the Grant Agency of the Czech Republic (203/05/0043) and by Gilead Sciences, Inc. (Foster City, CA).

[1] a) R. R. Breaker, Curr. Opin. Chem. Biol. 1997, 1, 26 31; b) M. Fa mulok, G. Mayer, M. Blind, Acc. Chem. Res. 2000, 33, 591 599; c) M. Famulok, Curr. Opin. Mol. Ther. 2005, 7, 137143.

[2] a) H. Hashimoto, M. G. Nelson, C. Schwitzer, J. Am. Chem. Soc. 1993, 115, 7128 7134; b) H. Rosemeyer, N. Ramzaeva, E. M. Becker, E. Feiling, F. Seela, Bioconjugate Chem. 2002, 13, 1274 1285 ; c) J. A. Brazier, T. Shibata, J. Townsley, B. F. Taylor, E. Frary, N. H. Williams, D. M. Williams, Nucleic Acids Res. 2005, 33, 1362 1371.

[3] a) J. Gierlich, G. A. Burley, P. M. E. Gramlich, D. M. Hammond, T. Carell, Org. Lett. 2006, 8, 3639 3642; b) G. Burley, J. Gierlich,
M. R. Mofid, H. Nir, S. Tal, Y. Eichen, T. Carell, J. Am. Chem. Soc. 2006, 128, 13981399.

[4] a) K. Sakthivel, C. F. Barbas, III, Angew. Chem. Int. Ed. 1998, 37, 2872 2875; b) H. Sawai, A. Ozaki Nakamura, M. Mine, H. Ozaki, Bioconjugate Chem. 2002, 13, 309 316; c) M. M. Masud, A. Ozaki Nakamura, M. Kuwahara, H. Ozaki, H. Sawai, ChemBioChem 2003, 4, 584 588; d) M. Kuwahara, J. Nagashima, M. Hasegawa, T. Tamura, R. Kitagata, K. Hanawa, S. Hososhima, T. Kasamatsu, H. Ozaki, H. Sawai, Nucleic Acids Res. 2006, 34, 5383 5394; e) T. Gourlain, A. Sidorov, N. Mignet, S. J. Thorpe, S. E. Lee, J. A. Grasby, D. M. Williams, Nucleic Acids Res. 2001, 29, 18981905.

[5] a) O. Thum, S. Jäger, M. Famulok, Angew. Chem. Int. Ed. 2001, 40 , 3990 3993; b) S. Jäger, M. Famulok, Angew. Chem. Int. Ed. 2004, 43, 3337 3340; c) S. Jäger, G. Rasched, H. Kornreich Leshem, M. Engeser, O. Thum, M. Famulok, J. Am. Chem. Soc. 2005, 127, 1507115082

[6] H. Sawai, A. N. Ozaki, F. Satoh, T. Ohbayashi, M. M. Masud, H. Ozaki, Chem. Commun. 2001, 26012605.

[7] A. Shoji, T. Hasegawa, M. Kuwahara, H. Ozaki, H. Sawai, Bioorg. Med. Chem. Lett. 2007, 17, 776779.

[8] a) D. A. Di Giusto, W. A. Wlassoff, S. Geisebrecht, J. J. Gooding, G. C. King, J. Am. Chem. Soc. 2004, 126, 4120 4121; b) D. A. Di G iusto, W. A. Wlassoff, S. Geisebrecht, J. J. Gooding, G. C. King, Angew. Chem. Int. Ed. 2004, 43, 2809 2812; c) W. A. Wlassoff, G. C. King, Nucleic Acids Res. 2002, 30, e58; d) S. S. W. Yeung, T. M. H Lee, I M. Hsing, J. Am. Chem. Soc. 2006, 128, 1337413375.

[9] M. Kuwahara, K. Hanawa, K. Ohsawa, R. Kitagata, H. Ozaki, H. Sawai, Bioorg. Med. Chem. 2006, 14, 25182526.

[10] M. Matsui, Y. Nishiyama, S. Ueji, Y. Ebara, Bioorg. Med. Chem. Lett. 2007, 17, 456460.

[11] L. H. Thoresen, G. S. Jiao, W. C. Haaland, M. L. Metzker, K. Bur gess, Chem. Eur. J. 2003, 9, 46034610.

[12] P. Čapek, R. Pohl, M. Hocek, Org. Biomol. Chem. 2006, 4, 2278 2284.

[13] a) E. C. Western, J. R. Daft, E. M. Johnson, P. M. Gannett, K. H. Shaughnessy, J. Org. Chem. 2003, 68, 6767 6774; b) E. C. Western K. H. Shaughnessy, J. Org. Chem. 2005, 70, 6378 6388; c) recent comprehensive review: K. H. Shaughnessy, Eur. J. Org. Chem. 2006, 18271835.

[14] A. Collier, G. Wagner, Org. Biomol. Chem. 2006, 4, 45264532.

[15] Reviews: a) M. Hocek, Eur. J. Org. Chem. 2003, 245 254; b) L. A Agrofoglio, I. Gillaizeau, Y. Saito, Chem. Rev. 2003, 103, 1875 1916; c) M. K. Lakshman, J. Organomet. Chem. 2002, 653, 234251.

[16] P. Čapek, M. Hocek, Synlett 2005, 30053007.

[17] P. Čapek, M. Vrábel, Z. Hasník, R. Pohl, M. Hocek, Synthesis 2006, 35153526.

[18] J. M. Clark, Nucleic Acids Res. 1988, 16, 9677.

[19] M. Ikehara, M. Kaneko, Chem. Pharm. Bull. 1970, 18, 24412446.

[20] L. S. Gordeeva, Yu. L. Kaminskii, N. L. Rumyantseva, N. A. Patoki na, N. A. Korsakova, L. F. Chernysheva, V. K. Dedova, V. L. Efimo va, A. G. Neopikhanova, Khim. Prir. Soedin. 1984, 6, 771776.

[21] F. Seela, M. Zulauf, H. Rosemeyer, H. Reuter, J. Chem. Soc. Perkin Trans. 2 1996, 23732376.

[22] T. Kovacs, L. Ötvös, Tetrahedron Lett. 1988, 29, 45254528. 